\title{
Annual Phytoplankton Primary Production Estimation in a Temperate Estuary by Coupling PAM and Carbon Incorporation Methods
}

\author{
Morelle Jérôme ${ }^{1,2}$, Schapira Mathilde ${ }^{3}$, Orvain Francis ${ }^{1,2}$, Riou Philippe ${ }^{3}$, Lopez Pascal Jean ${ }^{2}$, \\ Pierre-Duplessix Olivier ${ }^{3}$, Rabiller Emilie ${ }^{3}$, Maheux Frank ${ }^{3}$, Simon Benjamin ${ }^{3}$, Claquin Pascal ${ }^{1,2,}$,
}

\author{
${ }^{1}$ Normandie Université, Université de Caen Normandie, F-14032 Caen, France \\ ${ }^{2}$ UMR Biologie des ORganismes et Ecosystèmes Aquatiques (BOREA), Muséum National d'Histoire \\ Naturelle, CNRS-7208, IRD-207, Sorbonne Université, Université Caen-Normandie, Université des \\ Antilles, Esplanade de la paix, F-14032 Caen, France \\ ${ }^{3}$ Ifremer, LER/N, Avenue du Général de Gaulle, 14520 Port-en-Bessin, France \\ *Corresponding author : Pascal Claquin, email address : pascal.claquin@unicaen.fr
}

\begin{abstract}
:
Phytoplankton primary production varies considerably with environmental parameters especially in dynamic ecosystems like estuaries. The aim of this study was to investigate short-term primary production along the salinity gradient of a temperate estuary over the course of 1 year. The combination of carbon incorporation and fluorescence methods enabled primary production estimation at short spatial and temporal scales. The electron requirement for carbon fixation was investigated in relation with physical-chemical parameters to accurately estimate primary production at high frequency. These results combined with the variability of the photic layer allowed the annual estimation of primary production along the estuary. Phytoplankton dynamics was closely related to salinity and turbidity gradients, which strongly influenced cells physiology and photoacclimatation. The number of electrons required to fix $1 \mathrm{~mol}$ of carbon $(\mathrm{C})$ was ranged between 1.6 and $25 \mathrm{~mol}$ electron mol C-1 with a mean annual value of $8 \pm 5 \mathrm{~mol}$ electron mol C-1. This optimum value suggests that in nutrient replete conditions like estuaries, alternative electron flows are low, while electrons transfer from photosystem II to carbon fixation is highly efficient. A statistical model was used to improve the estimation of primary production from electron transport rate as a function of significant environmental parameters. Based on this model, daily carbon production in the Seine estuary (France) was estimated by considering light and photic zone variability. A mean annual daily primary production of $0.12 \pm 0.18 \mathrm{~g} \mathrm{C} \mathrm{m}-2$ day-1 with a maximum of $1.18 \mathrm{~g} \mathrm{C} \mathrm{m-2} \mathrm{day-1} \mathrm{in} \mathrm{summer} \mathrm{was} \mathrm{estimated} \mathrm{which} \mathrm{lead} \mathrm{to} \mathrm{an} \mathrm{annual} \mathrm{mean} \mathrm{of}$ $64.75 \mathrm{~g} \mathrm{C} \mathrm{m}-2$ year-1. This approach should be applied more frequently in dynamic ecosystems such as estuaries or coastal waters to accurately estimate primary production in those valuable ecosystems.
\end{abstract}

Keywords: High frequency, Electron requirement for carbon fixation, Electron transport rate (ETR), Seine estuary 


\section{Acknowledgment}

The authors wish to thank those who participated in the sampling campaigns and in the evening sampling treatments, especially Matthieu Filoche, Guillaume Izabel and the technical staff of the CREC - marine station of Luc-sur-Mer. Authors also want to thanks Laurent Perez for his implication in the conception of sampling device. This work was support by the GIP Seine-Aval project "PROUESSE".

\section{Introduction}

Phytoplankton primary production (PPP) is one of the most important process in aquatic ecosystems which is at the base of the marine trophic network (Pauly and Christensen 1995; Chen and Borges 2009; Cloern et al. 2014). It is therefore essential to accurately estimate the PPP to understand, apprehend and manage the ecosystems. However, PPP varies considerably with environmental parameters (Cloern 1996; Pannard et al. 2008), including light availability (Falkowski and Raven 1997; Anning et al. 2000; Macintyre et al. 2002), nutrient concentrations (Dortch and Whitledge 1992; Lohrenz et al. 1999; Tillmann et al. 2000; Claquin et al. 2010) and temperature (Davison 1991; Falkowski and Raven 1997; Shaw and Purdie 2001; Claquin et al. 2008). The most commonly used methods for in situ estimation of PPP are carbon isotopes $\left({ }^{14} \mathrm{C}\right.$ or ${ }^{13} \mathrm{C}$ ) incorporation (Babin et al. 1994; Cloern et al. 2014) methods. Carbon isotopes methods are sensitive but the long incubation periods required are a disadvantage for accurate estimations at small spatial and temporal scales. The PAM (Pulse amplitude modulated) fluorometer method based on variations in the fluorescence emitted by the photosystem II (PSII) during photosynthesis allows rapid measurements of photosynthetic parameters (Parkhill et al. 2001; Kromkamp and Forster 2003; Napoléon and Claquin 2012). In contrast to the carbon incorporation method, which gives the rate of photosynthetic carbon incorporated, the PAM method gives access to the electron transport rate (ETR) from the PSII (Kolber and Falkowski 1993; Barranguet and Kromkamp 2000). The combination of these both methods allows to estimate the number of electrons required to fix one mol of carbon. Therefore, PPP can be estimated at small spatial and temporal scales as a function of the environmental parameters (Napoléon and Claquin 2012; Lawrenz et al. 2013; Hancke et al. 2015) and previous studies have shown that the estimation of the PPP by this way was as accurate than other traditional incubation methods such as carbon isotopes incorporation or oxygen measurements (Hartig et al. 1998; Barranguet and Kromkamp 2000; Kromkamp and Forster 2003; Morris and Kromkamp 2003).

The variability of environmental factors that could influence PPP is particularly high in dynamic ecosystems such as estuaries (Underwood and Kromkamp 1999; Cloern et al. 2014). These dynamic ecosystems are characterized by high variability at seasonal and tidal scales. Located at the interface between land and sea, estuaries are influenced by the freshwater outflow from the river and the marine water inflow from the tide. These ecosystems are known to play therefore important role in biogeochemical cycles (Chen and Borges 2009). Along the estuaries, PPP is affected by several gradients (i.e. salinity, turbidity, nutrient concentrations and light availability) caused by the dilution of the marine water brought by the tide with fresh water from the river (Kimmerer et al. 2012). PPP is usually the lowest within the maximum turbidity zone (MTZ) created by tidal asymmetries in particle transport brought about by the effect of gravitational circulation on tidal flows (Sanford et al. 2001) which induce low light penetration, salt stress and cell lysis (Goosen et al. 1999). Despite the large number of studies on temporal variations of PPP in estuaries, very few studies have been conducted at small spatial and temporal scales (Parizzi et al. 2016) and many large 
estuaries are still poorly studied. This is the case of the Seine estuary, which represents the largest outflow into the English Channel. Thus, the aims of this study were: (1) to investigate monthly the time and space dynamics of photosynthetic parameters along the estuary by using high frequency measurements during one year and identify the main factors controlling those parameters, (2) to explore the relationships between ETR and C fixation as a function of environmental factors, (3) to apply the multi-factorial relationships obtained on the whole ETR data set in order to estimate PPP from daily to annual scale.

\section{Methods}

\subsection{Study site}

The Seine River and its estuary drains a watershed covering $76,260 \mathrm{~km}^{2}$. After Paris, the river flows northwest and drains its water into the English Channel. Located $202 \mathrm{~km}$ from Paris (the kilometric scale of the Seine River is set at $0 \mathrm{~km}$ in the center of Paris), the weir at Poses (Fig. 1) represents the upper limit of the tidal propagation in the Seine estuary. The annual average river discharge at Poses is $436 \mathrm{~m}^{3} \cdot \mathrm{s}^{-1}$ with a flood period extending from December to April when the discharge reaches $1200-2500 \mathrm{~m}^{3} \cdot \mathrm{s}^{-1}$ and a low-flow period with a discharge of around $250 \mathrm{~m}^{3} \cdot \mathrm{s}^{-1}$ (Data GIP Seine-Aval, 2008; 2011). In the oligohaline part, salinity ranges from 0.5 to 5 ; in the mesohaline part salinity ranges from 5 to 18 ; in the polyhaline part from 18 to 30 ; and in the euhaline part salinity is above 30 . The Seine estuary is a macrotidal type estuary, with a tidal amplitude ranging from 3-7 $\mathrm{m}$ at Honfleur and 1-2 m at Poses. The mean residence time in the estuary varies between 17-18 days for a discharge of $200 \mathrm{~m}^{3} \mathrm{~s}^{-1}$ at Poses and between 5-7 days for a discharge of $1000 \mathrm{~m}^{3} \mathrm{~s}^{-1}$ (Brenon and Hir 1999; Even et al. 2007). The tide in the Seine estuary is characterized by flattening at high tide lasting more than 2 hours due to the deformation of the tidal wave during the propagation at shallow depths (Brenon and Hir 1999; Wang et al. 2002). The flow is asymmetric in favor of the flood and this trend increases as the tide propagates up the estuary. Seasonally, water temperature ranges between $25^{\circ} \mathrm{C}$ in summer and $7{ }^{\circ} \mathrm{C}$ in winter with differences of less than $1{ }^{\circ} \mathrm{C}$ along the longitudinal profile and a weak vertical gradient (Data GIP Seine-Aval, 2008; 2011). The MTZ, containing up to $2 \mathrm{~g} \mathrm{~L}^{-1}$ of suspended particulate matter (SPM), is most often located between Honfleur and Tancarville, but can move upstream depending on the intensity of the tide and river discharge. During winter flood events, the MTZ can be flushed out into the Seine Bay (Etcheber et al. 2007; Garnier et al. 2010).

\subsection{Sampling strategy}

Sampling was conducted monthly from January to December 2015 onboard the Ifremer ship "Delphy" at eight sampling sites scattered along the salinity gradient (Fig 1). The sites were distributed from the euhaline zone (site 1) to the oligohaline zone ( site 8). In order to sample a steady waterbody along the estuary, sampling was performed every month in spring tides conditions (tidal coefficient 90) during daylight and during the flattening of the high tide, which, in these conditions, lasts up to three hours along the Seine estuary. Along the salinity gradient, from site 1 to site $8, \mathrm{P} / \mathrm{E}$ curves were performed at high frequency with five minutes intervals in sub-surface water using the PAM method providing almost 40 distinct measurements along the transect. The device already used in (Napoléon et al. 2012 , 2014) that made it possible to carry out these measurements at high frequency is presented in figure 2 . In 
parallel, salinity (measured using the Practical Salinity Unit; PSU), turbidity (measured using the Nephelometric Turbidity Unit; NTU) and temperature $\left({ }^{\circ} \mathrm{C}\right)$ were recorded in vertical profiles at each site using a SBE 19-plusVD CTD (Seabird) from the sub-surface down to $1 \mathrm{~m}$ above the water-sediment interface (WSI). At each sampling site, water was sampled from the sub-surface (i.e. $1 \mathrm{~m}$ ) with a pump for analysis of the physical-chemical (nutrients, SPM) and biological parameters (chl $a, \mathrm{~F}_{\mathrm{V}}: \mathrm{F}_{\mathrm{M}}$ ). At sites 2, 4, $6 \& 8$, sampling was also conducted from $1 \mathrm{~m}$ above the WSI with a $5 \mathrm{~L}$ Niskin bottle and at these sites, a part of the water samples from sub-surface was used to estimate primary production using the ${ }^{13} \mathrm{C}$ incorporation method.

\subsection{Physical-chemical parameters}

\subsubsection{Nutrients}

To determine the concentration of nutrients $\left(\mathrm{PO}_{4}{ }^{3-}, \mathrm{NO}_{3}{ }^{-}, \mathrm{NO}_{2}{ }^{-}, \mathrm{NH}_{4}{ }^{+}\right.$and $\left.\mathrm{Si}(\mathrm{OH})_{4}\right), 100 \mathrm{ml}$ water samples were pre-filtered through a $48 \mu \mathrm{m}$ Nylon Mesh (Sefar Nitex 03-48/31-102 cm; Open area \%: 30) directly from the Niskin bottle in order to already eliminate a major part of the particles (Aminot and Kérouel 2004, 2007) and stored at $4^{\circ} \mathrm{C}$ until analysis. For the determination of concentrations of silicate $\left(\mathrm{Si}(\mathrm{OH})_{4}\right)$, water samples were subsequently filtered through a $0.45 \mu \mathrm{m}$ acetate cellulose membrane and stored at $4{ }^{\circ} \mathrm{C}$ until analysis. For the determination of dissolved inorganic nitrogen (i.e. $\left.\mathrm{DIN}=\mathrm{NO}_{3}^{-}+\mathrm{NO}_{2}^{-}+\mathrm{NH}_{4}^{+}\right)$and phosphate concentrations $\left(\mathrm{PO}_{4}^{3-}\right)$, water samples were immediately stored at $-20^{\circ} \mathrm{C}$. The samples were analyzed within one month after field collection with an autoanalyzer (Technicon III) following standard protocols (Aminot and Kérouel 2007; Hydes et al. 2010). The limits of quantification were $0.2 \mu \mathrm{M}$ for silicate, $0.1 \mu \mathrm{M}$ for nitrate, $0.02 \mu \mathrm{M}$ for nitrite, $0.04 \mu \mathrm{M}$ for phosphate and $0.1 \mu \mathrm{M}$ for ammonia.

\subsubsection{Suspended particulate matter}

Suspended particulate matter (SPM) was filtered following the method of Aminot \& Chaussepied (1983). The concentration of SPM in each sample was obtained after filtration (filtrated volume ranging from 0.1 to $1 \mathrm{~L}$ depending on turbidity) and drying for $24 \mathrm{~h}$ at $50{ }^{\circ} \mathrm{C}$ on pre-weighed calcined (i.e. $6 \mathrm{~h} ; 450{ }^{\circ} \mathrm{C}$ ) $\mathrm{GF} / \mathrm{F}$ filters $(47 \mathrm{~mm}$, $0.7 \mu \mathrm{m})$. Filters were rinsed with distilled water to remove any remaining salt. This strategy ensured a precision of 0.0001 g.L $\mathrm{L}^{-1}$ for the lowest SPM concentrations (Verney et al. 2009).

\subsection{Biomass measurements}

Phytoplankton biomass was assessed based on chlorophyll $a$ (chla) concentrations. Samples (30-500 ml) were filtered in triplicate through glass-fiber filters (Whatman, GF/F, $47 \mathrm{~mm}, 0.7 \mu \mathrm{m}$ ) and immediately frozen $\left(-20{ }^{\circ} \mathrm{C}\right.$ ) until analysis. In the laboratory, pigments were extracted in $10 \mathrm{~mL}$ of $90 \%(\mathrm{v} / \mathrm{v})$ acetone for $12 \mathrm{~h}$ in the dark at $4{ }^{\circ} \mathrm{C}$. After centrifugation at $2000 \mathrm{~g}$ for 10 minutes at $4{ }^{\circ} \mathrm{C}$, the concentration of chl $a$ were measured on extracts according to the fluorometric method of Lorenzen (1966) using a Turner Trilogy fluorometer (Turner Designs, Sunnyvale, California, USA). 


\subsection{Estimation of primary production}

\subsubsection{PAM fluorometry}

For the high-frequency estimation of primary production, the maximum quantum yield of photosystem II (PSII) $\left(\mathrm{F}_{\mathrm{V}}: \mathrm{F}_{\mathrm{M}}\right)$ was measured at 5 minute intervals using the flow through (FT) version of the WATER PAM (Waltz, Effeltrich, Germany) (Schreiber et al, 1986). Sub-surface water was collected through a pipe leading to a thermally insulated dark reserve that maintained the sample at the in situ temperature (Fig. 2). After 5 min of dark acclimation, which was sufficient for the oxidation of the Quinone $A\left(Q_{A}\right)$ pool in this highly turbid environment, a sub-sample was automatically transferred into the measuring chamber. The sample was excited by a weak blue light (1 $\mu$ mol. $\mathrm{m}^{-2} \cdot \mathrm{s}^{-1}, 470 \mathrm{~nm}$, frequency $\left.0.6 \mathrm{kHz}\right)$ to record the minimum fluorescence $\left(\mathrm{F}_{0}\right)$. Maximum fluorescence $\left(\mathrm{F}_{\mathrm{M}}\right)$ was obtained during a saturating light pulse $\left(0.6 \mathrm{~s}, 1700 \mu \mathrm{mol} \cdot \mathrm{m}^{-2} \cdot \mathrm{s}^{-1}, 470 \mathrm{~nm}\right)$ allowing all the Quinone $\mathrm{A}\left(\mathrm{Q}_{\mathrm{A}}\right)$ pool to be reduced. $\mathrm{F}_{\mathrm{V}}: \mathrm{F}_{\mathrm{M}}$ was calculated according to the following equation (Genty et al. 1989):

$\frac{F_{V}}{F_{M}}=\frac{\left(F_{M}-F_{0}\right)}{F_{M}}$

Consecutively, samples were exposed to nine irradiances (E) from 0 to $469 \mu \mathrm{mol}$ photon. $\mathrm{m}^{-2} \cdot \mathrm{s}^{-1}$ from January to July and from 0 to 1541 from August to December for $30 \mathrm{~s}$ for each light step. Steady state fluorescence $\left(\mathrm{F}_{\mathrm{S}}\right)$ and maximum fluorescence $\left(\mathrm{F}_{\mathrm{M}}{ }^{\prime}\right)$ were measured. The effective quantum yield of PSII for each irradiance was determined as follows (Genty et al. 1989):

$\frac{\Delta \mathrm{F}}{\mathrm{F}_{\mathrm{M}}{ }^{\prime}}=\frac{\left(\mathrm{F}_{\mathrm{M}}{ }^{\prime}-\mathrm{F}_{\mathrm{S}}\right)}{\mathrm{F}_{\mathrm{M}}{ }^{\prime}}$

The relative electron transport rate (rETR, rel.unit) was calculated for each irradiance. rETR is a measure of the rate of linear electron transport through PSII, which is correlated with the overall photosynthetic performance of the phytoplankton (Juneau and Harrison 2005) :

$\operatorname{rETR}(\mathrm{E})=\frac{\Delta \mathrm{F}}{\mathrm{F}_{\mathrm{M}}{ }^{\prime}} \times \mathrm{E}$

At each site, a sample of both sub-surface water and water at the WSI were taken and dark adapted for 5 min. A sub-sample was inserted into the measuring chamber of the cuvette version of the WATER PAM (Waltz, Effeltrich, Germany) and rETR versus E curves were performed as described above.

Another dark adapted sub-sample was placed in a multi-color PAM (Waltz, Effeltrich, Germany) for estimation of the wavelength dependent functional cross-section of PSII $\left(\sigma_{\mathrm{PSII}}\right.$; expressed in $\left.\mathrm{m}^{2}\right)$ derived from the initial rise of fluorescence yield upon onset of saturating light intensity $(\lambda=440 \mathrm{~nm})$, which directly reflects the rate at which PSII centers are closed. This cross section may be visualized as the effective area of a PSII unit, exposed to a beam of photons, with the size of this area varying with the pigment composition and the color of the incident light (Schreiber et al. 2012). Calculation of $\sigma_{\mathrm{PSI} I 400}$ by the multi-color PAM software is based on the following equation (Klughammer and Schreiber 2015): 


$$
\sigma_{\mathrm{PSII}_{440}}=\frac{\mathrm{PAR}(\mathrm{II})}{\mathrm{L} \times \mathrm{PAR}}
$$

where L is Avogadro's constant, PAR is the quantum flux density of the light driving the O- $\mathrm{I}_{1}$ rise expressed in $\mu \mathrm{mol}$ quanta/ $\left(\mathrm{m}^{2} \cdot \mathrm{s}^{-1}\right)$ and PAR(II) is the rate of quantum absorption in PS II expressed in units of quanta/(PSII.s $\left.{ }^{-1}\right)$. As explain by Schreiber et al. (2012), this definition of $\sigma_{\mathrm{PSII} 400}$ relates to the functional cross-section of PSII for the specific conditions under which the $\mathrm{O}-\mathrm{I}_{1}$ rise measurement was carried out. $\sigma_{\mathrm{PSII} 400}$ specifically applies for the reference state of a dark-adapted sample with open PSII reaction centers and oxidized PQ pool. It is not identical to the functional PSII cross-section defined by Kolber et al. (1998) and, hence, can be modulated by changes in the PQredox state and various types of non-photochemical quenching.

Consequently, based on PAR(II) which can be expressed from equation 4 as PAR(II) $=\sigma_{\text {PSII } 400} \mathrm{x}$ L x PAR, also a wavelength- and sample-dependent ETR(II) can be defined:

$\operatorname{ETR}(\mathrm{II})=\operatorname{PAR}(\mathrm{II}) \times \frac{\Delta \mathrm{F}: \mathrm{F}_{\mathrm{M}}{ }^{\prime}}{\mathrm{F}_{\mathrm{V}}: \mathrm{F}_{\mathrm{M}}}$

After application of the mechanistic model of Eilers \& Peeters (1988) to estimate $\mathrm{rETR}_{\max }$ from $\mathrm{rETR} / \mathrm{E}$ curves previously performed, and according to equation 4 and 5, as Schreiber et al. (2012), the maximum electron transport rate $(\text { ETR(II })_{\max }$ ) was calculated. Firstly, ETR(II) $)_{\max }$ was expressed in electron.(PSII.s $\left.{ }^{-1}\right)^{-1}$ using equation 6 and secondly ETR(II) $)_{\max }$ was expressed in mmol electron.mgchl ${ }^{-1} \cdot \mathrm{h}^{-1}$ according to the equation 7 :

$\left[\operatorname{ETR}(\mathrm{II})_{\max }\right]=\frac{\mathrm{rETRmax} \times \sigma_{\mathrm{PSII}} \times \mathrm{L}}{\mathrm{F}_{\mathrm{V}}: \mathrm{F}_{\mathrm{M}}}$

$\operatorname{ETR}(\mathrm{II})_{\max }=\frac{\left[\mathrm{ETR}(\mathrm{II})_{\max }\right] \times[\mathrm{PSII}] \times 36.10^{6}}{[\mathrm{chl} a] \times \mathrm{L}}$

with in equation $6, \mathrm{~F}_{\mathrm{V}}: \mathrm{F}_{\mathrm{M}}$ and $\mathrm{rETR}_{\max }$ (knowing that $\mathrm{rETR}=\mathrm{PAR} \times \Delta \mathrm{F}: \mathrm{F}_{\mathrm{M}}$ ') calculated above, L the Avogadro's constant in $\mathrm{mol}^{-1}$ and $\sigma_{\mathrm{PSII}}$ in $\mathrm{m}^{2}$. Then, in equation 7 , [ETR(II) $\left.)_{\max }\right]$ calculated from equation 6 and expressed in electron.(PSII.s $)^{-1}, 36 \times 10^{6}$ the factor to change units from seconds to hours and from mol to mmol, [chla] the chlorophyll concentration expressed in $\mathrm{mg} \cdot \mathrm{ml}^{-1}$ and [PSII] the concentration of PSII reaction centers in PSII.ml ${ }^{-1}$ obtained as follows:

$[\mathrm{PSII}]=\frac{[\mathrm{chl} a] \times \mathrm{L}}{900 \times 1000}$

where [chla] represent the overall chla content in the sample expressed in g.ml $^{-1}$ assuming as Schreiber et al. (2012) a molecular weight of 900 g. $\mathrm{mol}^{-1}$ per chl, an Avogadro's constant of 6.022 x $10^{23}$ molecules per mol and 1000 molecules of chl $a$ per PSII unit.

\subsection{2. ${ }^{13} \mathrm{C}$ Incorporation}

A photosynthetron (modified by Babin et al. (1994)) was used to incubate ${ }^{13} \mathrm{C}$ on the samples taken at sites 2,4 , 6 and 8. A U-shaped dimmable fluorescent tube (OSRAM, DULUX L, 2G11, 55W/12-950, LUMILUX DE LUXE, daylight) produced the light, and the temperature in the photosynthetron was maintained at the in situ temperature by 
a seawater circuit equipped with a water chiller (AQUAVIE ICE 400). A total of $1100 \mathrm{ml}$ of seawater was inoculated with $\mathrm{NaH}^{13} \mathrm{CO}_{3}$ (98 atom \%, Sigma) corresponding to an enrichment of about $15 \%$ of the dissolved inorganic carbon already present in the seawater. The inoculated seawater was shared among 16 culture flasks $(62 \mathrm{ml})$ placed in the photosynthetron. Light intensity was measured in each flask using a micro-spherical quantum sensor (US-SQS; Walz) connected to a LI-COR 1400 data logger. One of the flasks was kept in the dark to estimate incorporation of non-photosynthetic inorganic carbon. The light values ranged between 0 and $1550 \mu$ mol photons. $\mathrm{m}^{-2} \cdot \mathrm{s}^{-1}$.

After 3 hours of incubation, each flask was filtered onto $25 \mathrm{~mm}$ pre-combusted $\left(450{ }^{\circ} \mathrm{C}, 12 \mathrm{~h}\right) \mathrm{GF} / \mathrm{F}$ filters and stored at $-20^{\circ} \mathrm{C}$ until analysis. To remove carbonates, filters were exposed to fuming $\mathrm{HCl}$ for 4 hours and then dried at $50{ }^{\circ} \mathrm{C}$ for 12 hours. The concentration of particulate organic carbon (POC) and the isotopic ratio of ${ }^{13} \mathrm{C}$ to ${ }^{12} \mathrm{C}$ were determined using an elemental analyzer (EA 3000, Eurovector) combined with a mass spectrophotometer (IsoPrime, Elementar). As already discussed in previous studies (Lawrenz et al. 2013; Milligan et al. 2014; Hancke et al. 2015) concerning GPP (Gross Primary Production) and NPP (Net Primary Production) estimations, it is still debated for ${ }^{13} \mathrm{C}$ or ${ }^{14} \mathrm{C}$ incubation of few hours. The carbon fixation rate $\left(\mathrm{P}_{\mathrm{obs}}\right)$ was calculated according to Hama et al. (1983). The value for incorporation in the dark was subtracted from all data and $\mathrm{P}_{\mathrm{obs}}$ is expressed in mmol C. $\mathrm{L}^{-1} \cdot \mathrm{h}^{-1}$.

\subsubsection{P vs. E curves}

Each ETR(II) and $\mathrm{P}_{\mathrm{obs}}$ series were plotted against light (E). To estimate photosynthetic parameters, the mechanistic model of Eilers \& Peeters (1988) was applied to these plot using SigmaPlot 12.0 (Systat Software):

$X(E)=\frac{E}{\left(a E^{2}+b E+c\right)}$

, where $\mathrm{X}$ represents either ETR(II) or $\mathrm{P}_{\text {obs }}$. Thereby the maximum photosynthetic capacity (ETR(II) $)_{\max }$ or $\mathrm{P}_{\max }$ ) and the low maximum light utilization efficiency $(\alpha)$ were calculated as follows:

$$
\begin{aligned}
& X_{\text {max }}=\frac{1}{(b+2 \sqrt{a c})} \\
& \alpha=\frac{1}{c}
\end{aligned}
$$

\subsubsection{Estimation of the annual primary production}

Carbon incorporation $\left(\mathrm{P}_{\max }\right)$ was plotted against ETR(II) $)_{\max }$ to investigate the relationship between the two parameters. The electron requirement for $\mathrm{C}$ fixation $\left(\varphi_{\mathrm{e}, \mathrm{C}}\right)$ dynamics characterized by the slopes of the relationships (Napoléon et al. 2013b; Lawrenz et al. 2013) was also expressed. Successive multiple regressions were performed to identify the best relationship to estimate $\mathrm{P}_{\max }$ as a function of ETR(II) $)_{\max }$ but also as a function of the other physicalchemical parameters (temperature, salinity, DIN, P, Si and SPM) and this relationship was used to estimate simulated carbon incorporation $\mathrm{P}_{\max }^{\mathrm{sim}}\left(\mathrm{mgC} \cdot \mathrm{m}^{-3} \cdot \mathrm{h}^{-1}\right)$ and $\alpha^{\mathrm{sim}}\left(\mathrm{mgC} \cdot \mathrm{m}^{-3} \cdot \mathrm{h}^{-1} \cdot\left(\mu \mathrm{mol} \text { photon. } \mathrm{m}^{-2} \cdot \mathrm{s}^{-1}\right)^{-1}\right)$. The parameter $\mathrm{E}_{\mathrm{k}}$ was calculated as $\mathrm{E}_{\mathrm{k}}=\mathrm{rETR}_{\max } / \alpha$ and used to estimate $\alpha(\mathrm{II})$ from ETR(II) $)_{\max }$ and $\alpha^{\text {sim }}$ from $\mathrm{P}_{\text {max }}^{\text {sim }}$.

Finally, primary production was estimated for each site for the whole study year. PPP was estimated for each hour of daylight $(\mathrm{E})$ of the year and integrated with the depth of the photic zone as follows: 
$\operatorname{PPP}\left(\mathrm{mgC} \cdot \mathrm{m}^{-2} \cdot \mathrm{h}^{-1}\right)=\frac{n}{i} \times \int_{z_{0}=0.05}^{z_{\mathrm{i}}=\mathrm{n}} \mathrm{P}_{\max }^{\operatorname{sim}} \times\left(1-\mathrm{e}^{\left(-\alpha^{\mathrm{sim}} \times \frac{\mathrm{E}_{Z_{\mathrm{i}}}}{\mathrm{P}_{\max }^{\operatorname{sim}}}\right)}\right) \mathrm{dz}$

, where $z$ is the depth, $i$ the number of replicates, and $n$ the maximum depth of the photic zone (the limit of the photic zone was determined when $99 \%$ of the incident light was attenuated). $\mathrm{P}^{\mathrm{sim}}{ }_{\max }\left(\mathrm{mgC} \cdot \mathrm{m}^{-3} \cdot \mathrm{h}^{-1}\right)$ and $\alpha^{\text {sim }}$ (rel.unit) are the values previously calculated for each sampling month. $E_{z i}$ is the irradiance ( $\mu$ mol photon. $m^{-2} \cdot s^{-1}$ ) at depth $z_{i}$ calculated at $0.01 \mathrm{~m}$ intervals along the photic zone, which, in this study extended from 0 to $3.5 \mathrm{~m}(\mathrm{i}=35$ and $\mathrm{n}=3.5$ ), using the Beer-Lambert law as follows:

$\mathrm{E}_{\mathrm{z}_{\mathrm{i}}}=0.94 \times\left(\mathrm{E}_{\mathrm{z}_{0}} \times \mathrm{e}^{-\mathrm{kd} \times \mathrm{z}_{\mathrm{i}}}\right)$

, where $\mathrm{E}_{\mathrm{Z} 0}$ is the incident light at the surface obtained from the nearest national weather station (18 miles; $\left.29 \mathrm{~km}\right)$, 0.94 is the percentage of light penetration into the water. $\mathrm{k}_{\mathrm{d}}$ is the coefficient of light attenuation in the photic zone, which varied in space and over time at each site. The $\mathrm{k}_{\mathrm{d}}$ values were calculated with the PAR attenuation observed with the depth, both measured with the SBE profiles recorded during the sampling campaigns following the equation:

$P A R=a e^{-k_{d} \times z}$

Where PAR is the light ( $\mu$ mol photons.m-2.s-1) measured at each depth $(\mathrm{z})$. The different values of $\mathrm{k}_{\mathrm{d}}$ were estimated for each site and each month using the linear relationship found between turbidity (NTU) and the light attenuation coefficients $\left(\mathrm{k}_{\mathrm{d}}\right): \mathrm{k}_{\mathrm{d}}=0.1107 \mathrm{x}$ Turbidity $+0.588\left(\mathrm{R}^{2}=0.923\right)$. For turbidity ranging from 4.88 to 93.31 , the corresponding $\mathrm{k}_{\mathrm{d}}$ ranged from 1.13 to $10.92 \mathrm{~mm}^{-1}$. P:B ratio (mgC.mgchl $a^{-1} \cdot \mathrm{d}^{-1}$ ) was also estimated using these PPP estimations.

\subsection{Data analysis}

\section{Multivariate analyses}

In order to characterize the spatial and temporal variation diagram of the physical and chemical parameters, partial triadic analyses (PTA) were performed on the data set using the ADE-4 package (Chessel et al. 2004; Dray and Dufour 2007) with R software. Data were organized in sub-matrices for each site. The interstructure of the PTA consisted in comparing the structure shared between sub-matrices and in identifying sites with similar temporal structure. The second step consisted in constructing a compromise that enabled us to build a common temporal typology between matrices. The relationship between physical, chemical, biological and photosynthetic parameters was investigated by principal component analyses (PCA) using the ADE-4 package in R software. PCA was performed of the group of sites shown by PTA to have a similar annual structure.

\section{Univariate analyses}

In a complementary way, the linear dependence between parameters was established by linear regressions performed on R software and by calculation of Person correlation coefficient. All plots of the parameters dynamics were created using the SigmaPlot 12.0 software. The illustrative plots performed on the different parameters by 
taking into account the spatial and the temporal dynamics were previously smooth using the non-parametric method of local regression ("Loess"). To identify the physical-chemical parameters that significantly drive the ETR/P relationship, multiple regressions with temperature, salinity, nutrients concentrations (DIN, P and Si) and SPM were performed using a upward step-by-step method on R software.

\section{Results}

\subsection{Dynamics of hydrological parameters}

The dynamics of the physical and chemical parameters (irradiance, river flow, temperature, salinity, nutrients, turbidity and SPM) are characteristics for the Northern European estuaries and are therefore described in supplementary material. In order to investigate the seasonal pattern and the functioning of the estuary in a spatial context, a partial triadic analysis (PTA) was performed on physical and chemical parameters from sub-surface and deep waters.

\section{Interstructure analyses of the PTA}

In the interstructure analysis of the PTA, the two first eigenvectors represent respectively $78 \%$ and $10 \%$ of total inertia of the sub-surface waters (Fig. 3-A) and respectively $72 \%$ and $17 \%$ of total inertia of the bottom waters (Fig. 3-D). Projection of the sites on the first axis revealed the common temporal pattern among sites (Fig. 3-B\&E), in agreement with the high vector correlation coefficients (RV-coefficient) calculated (Table 1). Projection of the sites on the second axis divided the sampling transect into two zones and four distinct areas (Fig. 2-B) in agreement with Ward's clustering method (Fig. 3-C): (i) area 1 (Site 1\&2) and area 2 (Site 3\&4) grouped in zone A (Downstream), (ii) area 3 (Site 5\&6) and area 4 (Site 7\&8) grouped in zone B (Upstream). The weight values were similar for all the sites, showing that any site had a particular temporal pattern (Table 1). Thus, the Seine estuary can be divided in two zones as a function of the dynamics of the physical-chemical parameters: (i) a downstream zone (zone A) stretching from longitude 0.11 (site 1) to longitude 0.30 (site 4) and characterized by high salinity (combining the polyhaline (> 18) and mésohaline (> 5) zones), and (ii) an upstream zone (zone B) stretching from longitude 0.36 (site 5) to longitude 0.51 (site 8), characterized by lower salinity (combining the mésohaline $(<18)$ and oligohaline $(<5)$ zones) and higher turbidity.).

\section{Compromise analyses}

In the compromise analysis of the PTA, for sub-surface waters the two first eigenvectors represented $54 \%$ and $35 \%$ of total inertia (Fig. 4-A) and for bottom parameters $63 \%$ and $29 \%$ of total inertia (Fig. 4-D), providing an accurate summary of the common temporal trend among sites over the sampling year. Compromise analysis revealed a clear seasonal pattern in the physical-chemical parameters both in the sub-surface and deep waters (Fig. 4-B, C, E and F). The period from January to March was characterized by high DIN and Si concentrations, related to high river flow in winter. The increase in temperature in April was followed by an increase in salinity (related to the decrease in river flow) and in surface irradiance in May. The increase in phosphate concentrations between September and 
October was associated with the increase in SPM concentrations and turbidity. This period was also characterized by a decrease in irradiance and temperature, and in salinity in relation with the increase in river flow.

The dynamics of the physical and chemical parameters are given in supplementary material. The highest SPM and turbidity values were recorded near the limit of salt water intrusion in the upper part of the estuary that defined the MTZ. Its position is consequently influenced at daily and seasonal scales by variations of the tide and of the river flow. Since sampling was always carried out during spring tides, the localization of the MTZ, was only controlled by the Seine river flow. Consequently, the MTZ was located downstream of zone B during the high-flow period and upstream during the low-flow period. Within both zones, high DIN and Si concentrations were negatively related to salinity and positively with river flow, suggesting a strong control by freshwater outputs. Indeed, in the Seine river, a large part of the DIN pool originates from agricultural and industrial activities and urban discharges along its watershed (Garnier et al. 2010), while Si is weakly influenced by human activities (Sferratore et al. 2006; Aminot and Kérouel 2007). Despite the decrease in P in the Seine River in the last few years, due to the improved waste water treatment plants and the massive introduction of detergents without phosphates, high concentrations were nevertheless measured throughout the estuary (Némery and Garnier 2007; Passy et al. 2016). In this study, P concentrations varied differently than DIN and Si in the two zones: P was positively linked with turbidity and SPM in zone $\mathrm{A}$, whereas in the zone B, P concentrations were positively linked with salinity and negatively related to the Seine river flow. $\mathrm{P}$ is adsorbed onto suspended particles in the low-salinity and high turbidity part of estuaries, which can be explained by non-biological buffering mechanisms (Morris et al. 1981; Sharp et al. 1982; Némery and Garnier 2007). The positive relationship with SPM and turbidity in zone A together with the negative relationship with river flow in zone B, suggest the adsorption of P within the MTZ. The pool of P is then exported downstream by the SPM. The inverse relationship observed between $\mathrm{P}$ and river flow in zone $\mathrm{B}$ could be due to an accumulation of $\mathrm{P}$ during the low flow periods.

\subsection{Phytoplankton biomass and photosynthetic parameters}

The chlorophyll $a$ concentrations ranged from 0.2 to $15.9 \mu \mathrm{g} . \mathrm{L}^{-1}$. In sub-surface (Fig. 5-A), high concentrations of chla were recorded from May to September, and during this period, chla concentrations were increasing from upstream to downstream. The highest phytoplankton biomass in sub-surface $\left(15.9 \mu \mathrm{g} . \mathrm{L}^{-1}\right)$ was measured at site 2 in July and the lowest $\left(0.2 \mu \mathrm{g} . \mathrm{L}^{-1}\right)$ at site 4 in January. Close to the WSI (Fig. 5-B), in summer, the same gradient than in sub-surface was observed but with lower values: the highest value measured in July was $8.6 \mu$ g.L $\mathrm{L}^{-1}$ at site 2 . The lowest value $\left(0.4 \mu \mathrm{g} . \mathrm{L}^{-1}\right)$ was measured in zone A during January. Surprisingly, in zone B, high chla values (> 10 $\mu \mathrm{g} . \mathrm{L}^{-1}$, up to $21.8 \mu \mathrm{g} . \mathrm{L}^{-1}$ ) were recorded in winter.

The maximum quantum efficiency of PSII $\left(\mathrm{F}_{\mathrm{V}}: \mathrm{F}_{\mathrm{M}}\right)$, which represents the physiological state of the cells, showed distinctive dynamics in sub-surface in comparison with the bottom waters. In sub-surface (Fig. 5-C), $\mathrm{F}_{\mathrm{V}}: \mathrm{F}_{\mathrm{M}}$ were high in winter and spring with the highest value (0.67) measured in March at site 1 . In contrast, the lowest value $(<$ 0.01) was measured during summer (July) at site 8. In the upstream part of the estuary (Zone B), $F_{V}: F_{M}$ were low with values remaining frequently below 0.20. Close to the WSI (Fig. 5-D), the highest value (0.64) was measured at 
site 2 in May and the lowest $(<0.01)$ at site 8 in August. $F_{V}: F_{M}$ ratios close to the WSI showed high values in Zone A, with an average of 0.41 during the year, while in Zone $B$ the $F_{V}: F_{M}$ ratios remained low with an average of 0.16 during the studied period.

The high values of chla observed close to the WSI in winter were associated to very low values of $F_{\mathrm{V}}: \mathrm{F}_{\mathrm{M}}$ which indicates that this biomass is rather freshwater chlorophyll detrital matter than living phytoplankton.

The maximum light utilization efficiency $\left(\alpha(\mathrm{II})\right.$; mmol electron.mgchla $\left.{ }^{-1} \cdot \mathrm{h}^{-1} \cdot\left(\mu \mathrm{mol} \text { photon } \mathrm{m}^{-2} \cdot \mathrm{s}^{-1}\right)^{-1}\right)$, were highly

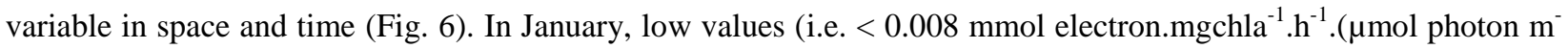
$\left.{ }^{2} \cdot \mathrm{s}^{-1}\right)^{-1}$ ) were recorded throughout the salinity gradient and within the MTZ area from January to March and from August to December. In May at longitude 0.4, a zone with values $<0.008$ was also recorded. Higher $\alpha$ (II) were observed during the rest of the year, with the highest values $\left(>0.012 \mathrm{mmol}\right.$ electron.mgchla ${ }^{-1} \cdot \mathrm{h}^{-1} \cdot\left(\mu \mathrm{mol} \mathrm{photon} \mathrm{m}^{-2} \mathrm{~s}-\right.$ $\left.{ }^{1}\right)^{-1}$ ) measured in the polyhaline zone (longitude < 0.2) between February and October. From February to December, a spatial gradient appeared to mirror the salinity gradient with decreasing values from downstream to upstream.

The dynamics of ETR(II) $\max$ (Fig. 7) showed low values (i.e. $<2$ mmol electron.mgchl ${ }^{-1} \cdot \mathrm{h}^{-1}$ ) throughout the salinity gradient in winter (January and February). ETR(II) $\max$ started to increase from March, firstly in the downstream part of the estuary and throughout the salinity gradient afterwards. The highest values were recorded from June to October throughout the salinity gradient. ETR(II) $\max$ were particularly high in the polyhaline zone with a maximum value of $10.8 \mathrm{mmol}$ electron.mgchl ${ }^{-1} \cdot \mathrm{h}^{-1}$ at site 2 in June. During this period of high ETR(II) $\max , \mathrm{values}$ gradually increased from upstream to downstream.

\subsection{Estimation of $\varphi_{e, C}$ and of primary production}

The combined PAM and carbon incorporation method was used to investigate the relationship between $\mathrm{P}_{\max }$ et ETR(II) $)_{\max }$ measurements (Napoléon and Claquin 2012; Lawrenz et al. 2013), and $\mathrm{P}_{\max }$ values were plotted against the ETR(II) $)_{\max }$ values (Fig. 8).

The electron requirement for $\mathrm{C}$ fixation $\left(\varphi_{\mathrm{e}, \mathrm{C}}\right.$; mol electron.molC $\left.{ }^{-1}\right)$, defined by the slope of the relationship between $\mathrm{P}$ and ETR, varied spatially and temporally ranging from 1.6 to 25 mol electron.molC ${ }^{-1}$ (Fig.9). A marked seasonal

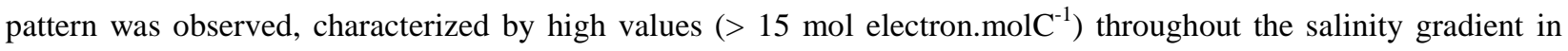
January and only in the downstream part in February and March (e.g. 25 mol electron.molC ${ }^{-1}$ at site 2 in March). High values were also estimated upstream during the summer (22.2 mol electron.molC ${ }^{-1}$ at site 8 in July). $\varphi_{\mathrm{e}, \mathrm{C}}$ values $<4$ mol electron.molC ${ }^{-1}$ were recorded twice: 1.6 mol electron.molC ${ }^{-1}$ at site 6 in May and 1.9 mol electron.molC ${ }^{-1}$ at site 8 in December. The mean $\varphi_{\mathrm{e}, \mathrm{C}}$ value was $8 \pm 5$ mol electron.molC ${ }^{-1}$.

To identify the physical-chemical parameters that drive this relationship between $\mathrm{P}$ and ETR(II), multiple regressions with temperature, salinity, nutrients concentrations (DIN, P and Si) and SPM were performed using an upward step-by-step method. A significant negative coefficient with DIN concentrations and a significant positive coefficient with temperature were observed. These two parameters were used to estimate the $P_{\max } d y n a m i c s(p<$ $\left.0.0001 ; \mathrm{R}^{2}=0.59\right)$ by using $\mathrm{ETR}(\mathrm{II})_{\max }$ according to the following equation:

$\mathrm{P}_{\max }^{\operatorname{sim}}=0.43-1.19 .10^{-2} \times \operatorname{ETR}(\mathrm{II})_{\max }-9.75 \cdot 10^{-4} \times[\mathrm{DIN}]+1.29 \cdot 10^{-2} \times$ Temperature 
A carbon incorporation at high frequency $\left(\mathrm{P}_{\text {max }}^{\mathrm{sim}}\right)$ and a maximum light utilization efficiency $\left(\alpha_{\text {sim }}=\right.$ ratio Ek /

$\mathrm{P}_{\text {max }}^{\text {sim }}$ ) were then estimated for each value of ETR(II $)_{\max }$ (Fig. 8). For each site, these values of $\mathrm{P}_{\text {max }}^{\text {sim }}$ and $\alpha_{\text {sim }}$ were used to estimate PPP at each hour of daylight (E) throughout the year by using a depth integrated equation of light penetration as a function of turbidity (equations 10\&11).

The dynamics of annual PPP showed high variability that differed at each time scale: at the hourly scale, values reached $110.4 \mathrm{mgC} \cdot \mathrm{m}^{-2} \cdot \mathrm{h}^{-1}$, at the daily scale, values reached $1.2 \mathrm{gC} \cdot \mathrm{m}^{-2} \cdot \mathrm{d}^{-1}$, and at the monthly scale values reached $26.1 \mathrm{gC} \cdot \mathrm{m}^{-2} \cdot \mathrm{month}^{-1}$ at site 2 in July (Table 2; Fig. 10). When considering all the sites, the highest PPP were observed in July, with a mean of $13.2 \mathrm{gC} \cdot \mathrm{m}^{-2} \cdot \mathrm{m}^{-1}$. Annual PPP was minimum at site 6 with a value of $17.3 \mathrm{gC} \cdot \mathrm{m}^{-2} \cdot \mathrm{y}^{-1}$ and maximum at site 2 with a value of $81.5 \mathrm{gC} \cdot \mathrm{m}^{-2} \cdot \mathrm{y}^{-1}$.

A representative area (in $\mathrm{km}^{2}$ ) was attributed to each site as a function of the water cover at high tide. Primary production values are expressed in $\mathrm{tC}_{\mathrm{y}} \mathrm{yr}^{-1}$ for each of these areas. Results revealed the prime role played by the mouth of the estuary (represented by site 1). Despite the better production capacity per $\mathrm{m}^{2}$ at site 2 , the area represented by site $1\left(44.38 \mathrm{~km}^{2}\right)$ led a higher carbon production with $3200 \mathrm{tC} \cdot \mathrm{yr}^{-1}$. When primary production was weighted as a function of the surface area of each site, the mean value for the annual PPP in the Seine estuary in 2015 was $64.75 \mathrm{gC} \cdot \mathrm{m}^{-2} \cdot \mathrm{y}^{-1}$.

The measured P:B ratio in sub-surface varied between 1 and $7.4 \mathrm{mgC} \cdot \mathrm{mgchl} a^{-1} \cdot \mathrm{h}^{-1}$ with a mean value of 4.2 $\mathrm{mgC} \cdot \mathrm{mgchl} a^{-1} \cdot \mathrm{h}^{-1}$. The spatial gradient of P:B ratio $\left(\mathrm{mgC} \cdot \mathrm{mgchl} a^{-1} \cdot \mathrm{d}^{-1}\right)$ integrated along the photic layer showed higher values downstream than upstream (Fig. 10). The maximum P:B ratio (19.6 mgC.mgchl $\left.a^{-1} \cdot \mathrm{d}^{-1}\right)$ was recorded in the mouth of the estuary in spring. In summer, the highest values were observed in the mesohaline part of the estuary.

\subsection{Principal Component Analyses}

Two principal component analyses (PCA) were performed to investigate the relationship between physicalchemical and biological parameters in the sub-surface waters (Fig. 11-A\&B) and bottom waters (Fig. 11-C\&D), the data sets representing the two zones defined by the PTA performed on physical-chemical parameters (Fig. 3). In zone A and zone B, the two first axes of the PCAs explained respectively $72 \%$ and $71 . \%$ of the total inertia for sub-surface waters, and for both, $76 \%$ of the total inertia for bottom waters. Analyses were thus based on these two axes.

For both zones (A and B), the parameters that contributed the most to axis 1 were salinity and temperature in one direction, and $\mathrm{Si}, \mathrm{DIN}$ and flow in the other direction for sub-surface waters. Regarding the second axis, the parameters that contributed the most were irradiance in one direction and turbidity and the SPM concentrations in the other direction. Despite their low contribution, chla concentrations were positively linked with temperature in both zones. Daily phytoplankton primary production (dPPP) and P:B ratio were positively linked with irradiance and temperature and negatively linked with turbidity. The $\mathrm{P}$ concentration varied between the two zones and was related to turbidity in zone $A$ and to salinity in zone $\mathrm{B}$. The variations in $\mathrm{F}_{\mathrm{V}}: \mathrm{F}_{\mathrm{M}}$ and $\alpha_{\text {sim }}$ were poorly explained by the physical-chemical parameters tested in both PCA.

In the bottom waters in zone A, the parameters that contributed the most to axis 1 were salinity and temperature in one direction and Si and DIN in the other direction. The parameters that contributed the most to axis 2 were the river 
flow in one direction, and SPM concentrations in the other. Despite their limited contributions, chla concentrations and $\mathrm{F}_{\mathrm{V}}: \mathrm{F}_{\mathrm{M}}$ were positively linked with salinity. In Zone $\mathrm{B}$, the parameters that contributed the most to axis 1 were salinity and $\mathrm{P}$ concentration in one direction and the river flow in the other direction. The parameters that contributed most to axis 2 were SPM and turbidity in one direction and temperature in the other direction. The biological parameters contributed more than in zone $\mathrm{A}$, and chl $a$ concentrations were positively linked with turbidity and $\mathrm{F}_{\mathrm{V}}: \mathrm{F}_{\mathrm{M}}$ positively linked with flow.

\section{Discussion}

\subsection{Phytoplankton biomass and the dynamics of photosynthetic parameters}

Nutrient concentrations were very high throughout the year and were not limiting for phytoplankton growth. Despite a negative relationship between chla and the concentrations of nutrients (DIN and $\mathrm{Si}$ ), the role of phytoplankton consumption on nutrient dynamics may have been weak in regards to the importance of nutrients fluxes which are mostly controlled by hydrodynamics (Kromkamp and Peene 2005). Classically, the dynamics of chl $a$ in nutrient-rich estuaries is mostly controlled by light availability, which varies with incident solar irradiance in the photic layers modulated by turbidity. The spatial dynamics of chla can be explained by the higher light availability downstream and osmotic stress in the most upstream part of the estuary which can lead to growth limitation and cell lysis (Lionard et al. 2005; Servais and Garnier 2006; Hernando et al. 2015). This stress could be confirmed by the low annual values of $\mathrm{F}_{\mathrm{V}}: \mathrm{F}_{\mathrm{M}}$ ratios $(<0.2)$ observed upstream. However, the presence of cyanobacteria in this part of the estuary (data not shown) could also explain the low level of $\mathrm{F}_{\mathrm{V}}: \mathrm{F}_{\mathrm{M}}$ ratios. $\mathrm{F}_{\mathrm{V}}: \mathrm{F}_{\mathrm{M}}$ ratios of cyanobacteria are known to be poorly estimated by PAM methods because of the contribution of phycobilisomes auto-fluorescence to $F_{0}$ background and the PSII:PSI ratio is small in cyanobacteria as opposite to diatoms for instance (Campbell et al. 1998; Masojidek et al. 2001; Macintyre et al. 2002; Suggett et al. 2004; Johnsen and Sakshaug 2007). The slightly higher $\mathrm{F}_{\mathrm{V}}: \mathrm{F}_{\mathrm{M}}$ ratios observed from January to April could also be attributed to freshwater species adapted to low salinity, low temperature and high turbidity as reported by in the Chesapeake bay. In zone A (downstream part), $\mathrm{F}_{\mathrm{V}}: \mathrm{F}_{\mathrm{M}}$ ratios in sub-surface waters were higher in winter (>0.4) than in summer $(<0.4)$ and inversely related to the concentrations of chla. The successive stress undergone in this zone could have led to a reduction in $\mathrm{F}_{\mathrm{V}}: \mathrm{F}_{\mathrm{M}}$ values especially with the high level of irradiance in summer. These reduction of $\mathrm{F}_{\mathrm{V}}: \mathrm{F}_{\mathrm{M}}$ can be due to photoprotection mechanisms or to alteration of PSII. As widely described, high irradiance may lead to a reduction of $\mathrm{F}_{\mathrm{V}}: \mathrm{F}_{\mathrm{M}}$ in sub-surface waters (Holm-Hansen et al. 2000; Shelly et al. 2003) due to the activation of short-term photoprotection mechanisms, such as xanthophyll cycling, which increases nonphotochemical quenching to protect cells against high levels of irradiance (Dubinsky and Stambler 2009; Goss and Jakob 2010). Moreover, the sub-surface layer can be defined as a fluctuating light environment caused by longitudinal and vertical mixing. In this type of environment, Alderkamp et al. (2010) have shown that phytoplankton cells need to balance more rapidly their photosynthetic machinery to maximize photoprotection at high irradiance and photosynthetic efficiency at low irradiance. Due to the turbidity level in estuary, acclimation to low light is principally require which induces a reduction in photo-protective pigment content. This reduction could lead to potential damage of photosystems when cells are exposed to high light on surface during summer (Alderkamp 
et al. 2010). Despite the low values of $F_{V}: F_{M}$ in summer in the downstream part, high values of $\alpha$ and ETR(II) max were measured allowing phytoplankton growth and high chla concentration. This discrepancy between $\alpha$, ETR(II) $\max$ and $\mathrm{F}_{\mathrm{V}}: \mathrm{F}_{\mathrm{M}}$ levels can be due to state transition mechanisms of cyanobacteria as previously described. These pattern were also observed upstream of the MTZ in the very low salinity zone. Despite low chl $a$ concentrations, the high photosynthetic values revealed a non-negligible capacity of the freshwater phytoplankton to contribute to photosynthesis in the estuary.

Regarding, the WSI values, high $\mathrm{F}_{\mathrm{V}}: \mathrm{F}_{\mathrm{M}}$ ratios was not expected because of the high level of detritic matter in this water layer. This result suggests that a large part of the phytoplankton biomass close to the WSI was composed of healthy cells.

\subsection{Carbon and ETR relationship}

The relation between ETR and carbon fixation was used to estimate carbon incorporation at high spatial frequency. The dynamics of the $\varphi_{\mathrm{e}, \mathrm{C}}$ showed strong temporal and spatial variability ranging between 1.56 and 24.98 mol electron.molC ${ }^{-1}$ with a mean value of $7.95 \pm 4.94$ mol electron.molC ${ }^{-1}$ over the course of the sampling year. Moreover, no spectral correction was performed in this study and our values were therefore overestimated by at least a factor of 1.5 or 2 (Lawrenz et al. 2013; Hancke et al. 2015). However, because no measurement of light spectrum was performed during this study, the choice was made to keep not corrected values to avoid arbitrary corrections using constant from literature.

Under optimal growth conditions, the value of $\varphi_{\mathrm{e}, \mathrm{C}}$. is comprised between 4 and 6 moles. The $\varphi_{\mathrm{e}, \mathrm{C}}$ values lower than 4 mol electron.molC ${ }^{-1}$ appear to be physically impossible and could be due to methodological, calculation errors (Lawrenz et al. 2013) or particular metabolic pathway (Bailleul et al. 2015). Indeed, values lower than 4 mol electron.molC ${ }^{-1}$ can be attenuated to an additional source of energy used in carbon fixation. It was recently shown that diatoms are able to optimize their photosynthesis through the exchange of energy between plastids and mitochondria (Bailleul et al. 2015). Indeed, when the ATP:NADPH ratio generated by a linear electron flow is insufficient to fuel $\mathrm{CO}_{2}$ imports into the plastid and assimilation by the Calvin cycle, diatoms are able to produced additional ATP via alternative pathways, particularly through extensive energy exchanges between plastids and mitochondria. This process could explain values of $\varphi_{\mathrm{e}, \mathrm{C}}<4 \mathrm{~mol}$ electron.molC ${ }^{-1}$. Moreover, as mentioned above, carbon incorporation during few hours provide an estimate between NPP and GPP, which entails a variability of $\varphi_{\mathrm{e}, \mathrm{C}}$ values (Lawrenz et al. 2013; Hancke et al. 2015) which need to be deeply studied (Milligan et al. 2014).

In this study, the average values of $\varphi_{\mathrm{e}, \mathrm{C}}$. were lower than those observed in previous studies (Kaiblinger and Dokulil 2006; Napoléon et al. 2013b) despite high environmental pressures. Environmental variations are the primary source of variations in electron transport and carbon fixation which can induce high values of $\varphi_{\mathrm{e}, \mathrm{C}}$. $\mathrm{such}$ as temperature (Morris and Kromkamp 2003), nutrient limitations (Babin et al. 1996; Napoléon et al. 2013b; Lawrenz et al. 2013; Schuback et al. 2015) or light stress (Napoléon and Claquin 2012; Zhu et al. 2016). The phytoplankton community assemblage can also influence the $\varphi_{\mathrm{e}, \mathrm{C}}$. values, however, this factor was not considered in the present study but will be investigated in a future work. We assume that the average value of $8 \mathrm{~mol} \mathrm{electrons.molC}^{-1}$ estimated in this study could be explained by the high nutrient level recorded in the estuary over the year. Indeed, 
Napoléon et al. (2013b) observed a large increase of the $\varphi_{\mathrm{e}, \mathrm{C}}$ under nutrient limitation, up to 125 mol electron.molC ${ }^{-1}$, therefore nutrient limitation seems to largely control the ETR/C relationship. Thus, in optimal nutrient conditions, even in stressful ecosystem as an estuary, the photosynthetic apparatus appears to be able to cope with environmental variations with ease.

Regarding metabolic regulation, the $\varphi_{\mathrm{e}, \mathrm{C}}$ values are due to alternative electron flow pathways (AEF) between PSII and $C$ fixation which therefore influence the ETR(II) $)_{\max } / \mathrm{P}_{\max }$ relationship. Such AEF (i.e. Mehler reaction, electron flow around PSI or/and PSII, photorespiration) modulate the ATP:NADPH ratio as a function of the metabolic demand to optimize photosynthetic performance and growth (Endo and Asada 2008; Nogales et al. 2011; Johnson and Alric 2013). Thus, the more AEF is important in comparison to LEF (linear electron flow), the more $\varphi_{\mathrm{e}, \mathrm{C} .}$ is high and will potentially bias the estimation of carbon incorporation using the ETR(II $)_{\max }$ measurements.

In this context, it is still important to investigate the variation in the ETR(II) $)_{\max } / \mathrm{P}_{\max }$ relationship (i.e $\varphi_{\mathrm{e}, \mathrm{C} \text {.) as a }}$ function of environmental parameters. In our study, a statistic relationship was determined considering the temperature and the DIN as significant environmental parameters. This was in agreement with previous studies that have explored such a statistical relationships between ETR and C fixation which underlined the importance of temperature, nutrients and light (Napoléon and Claquin 2012; Lawrenz et al. 2013). However, the influence rate of each parameter differs from a system to another and it still necessary to investigate the contribution of each environmental variable in different studied area.

\subsection{Phytoplankton primary production along the Seine Estuary}

Estimated daily carbon production in the Seine estuary reached $1.18 \mathrm{gC} \cdot \mathrm{m}^{-2} \cdot \mathrm{d}^{-1}$ in summer. Logically, primary production was higher in summer when river flow and turbidity are lower and when temperature and irradiance level are higher. These values are in agreement with some studies carried out worldwide in temperate estuaries, which reached maximum values of $4.2 \mathrm{gC} \cdot \mathrm{m}^{-2} \cdot \mathrm{d}^{-1}$ in the Delaware (Pennock and Sharp 1986 and citations therein), 1.7 $\mathrm{gC} \cdot \mathrm{m}^{-2} \cdot \mathrm{d}^{-1}$ in the Chesapeake (Magnien et al. 1992) in the east coast of the USA, $2.9 \mathrm{gC} \cdot \mathrm{m}^{-2} \cdot \mathrm{d}^{-1}$ in the Schelde in Europe (van Spaendonk et al. 1993 and citations therein), $1.17 \mathrm{gC} \cdot \mathrm{m}^{-2} \cdot \mathrm{d}^{-1}$ in the Lena in Russia (Sorokin and Sorokin 1996), and $2 \mathrm{gC} \cdot \mathrm{m}^{-2} \cdot \mathrm{d}^{-1}$ in the Chanchiang in China (Ning et al. 1988).

In order to understand variations in photosynthetic performance in space and over time, phytoplankton P:B ratio was investigated. The P:B ratio values were in accordance with previous studies performed in the English Channel coastal systems (Jouenne et al. 2007; Pannard et al. 2008; Napoléon and Claquin 2012). In the Seine estuary, the P:B ratio showed a seasonal pattern with low values under a temperature of $10{ }^{\circ} \mathrm{C}$ and high values in spring and summer especially in zone A (Fig. 3). The weak P:B ratio in zone B could be explained by turbidity, especially from July when levels increased up to 120 NTU. During the spring bloom, induced by increasing temperature and irradiance levels (Hunter-Cevera et al. 2016), P:B ratio was higher inside the estuary in summer. Usually in coastal waters, the consumption of nutrients in spring becomes limiting in summer and results in lower P:B ratio (Napoléon et al. 2012, 2013a). In the Seine estuary, in summer, P:B ratio was higher inside the estuary than nearby coastal waters. This result pointed out an important autochthonous PPP in summer induced by the tradeoff between nutrient and light availability which support estuarine food web in addition to input from the coastal water during the flow. 


\subsection{Estimation of annual phytoplankton primary production in the Seine estuary}

As a function of the sampling site, the annual PPP ranged between 17.26 and $81.53 \mathrm{gC} \cdot \mathrm{m}^{-2} \cdot \mathrm{y}^{-1}$. By taking each surface area into account (table 2), annual PPP represented a total of $6032 \mathrm{tC} . \mathrm{yr}^{-1}$ and a mean annual PPP of 64.75 $\mathrm{gC} \cdot \mathrm{m}^{-2} \cdot \mathrm{y}^{-1}$. This annual PPP is low compared with the range of annual mean PPP reported for 45 estuaries by Boynton et al. (1982) varying from 19 to $547 \mathrm{gC} \cdot \mathrm{m}^{-2} \cdot \mathrm{y}^{-1}$ with a mean of $190 \mathrm{gC} \cdot \mathrm{m}^{-2} \cdot \mathrm{y}^{-1}$ or for the 1148 measurements recorded in 131 estuarine and coastal ecosystems (estuaries, fjords, bays and lagoons) reported by Cloern et al. (2014), which ranged from -105 to $1890 \mathrm{gC} \cdot \mathrm{m}^{-2} \cdot \mathrm{y}^{-1}$ with a mean of $225 \mathrm{gC} \cdot \mathrm{m}^{-2} \cdot \mathrm{y}^{-1}$. In this context, and according to the classification of Nixon (1995), the Seine estuary can be classified as an oligotrophic system $\left(<100 \mathrm{gC} \cdot \mathrm{m}^{-2} \cdot \mathrm{y}^{-1}\right)$. However, our results showed a nutrient independent system which cannot be classified like this cause an estuary is not poor in terms of nutrients concentrations but still present a low primary production. It seems that a low PPP is not necessarily representative of an oligotrophic system but sometimes of a dynamic and complex system. Indeed, a wide range of variability within or between ecosystems and estuaries, sampling effort and methods may explain this range. Some environmental dynamics like temperature or the level of irradiance are determined by the geographic location or by bathymetric, hydrodynamic or morphologic characteristics. We must therefore be wary when comparing the various estuarine systems. In the Seine estuary, the low PPP value is principally due to the intense turbidity. It is also important to note that we focused the sampling strategy on salinity gradient without considering the upper freshwater part of the estuary. PPP of this upper part can be high (Descy et al. 2016) and can considerably contribute to the estuarine trophic network in terms of POC (Etcheber et al. 2007). Sampling effort also explain a large part of the discrepancy of annual PPP estimations between worldwide estuaries. Some authors based their annual estimation on few sites (Vegter 1977; Mallin et al. 1993) or made over a period of a couple of months in spring or summer (Smith and Kemp 1995) and extrapolates their results over a year. In the present study, the spatial variability was taken into account with high frequency measurements distributed all along the salinity gradient even in the less productive areas (MTZ) and during the less productive season (winter). Indeed, in our study, the four most downstream areas (sites 1 to 4) produced 5239 tC during the six more productive months (from April to September), which represent $87 \%$ of the total annual PPP. This trivial example highlights the limit of this type of classification strongly related to sampling strategy and effort.

\section{Conclusion}

The measurement and estimation methods presented in this paper improved the phytoplankton primary production estimation along the salinity gradient of a temperate estuary. The combination of high frequency and traditional methods in relation with the environment dynamics has shown the possibility of making accurate estimation of PPP at small-scale in these highly dynamic systems, and could be applied more frequently in valuable ecosystems such as estuaries or coastal waters to apprehend their functioning. We pointed out a quite low variability of the $\varphi_{\mathrm{e}, \mathrm{C}}$ because of nutrient replete conditions which allow to used variable fluorescence technics (PAM, FRRf) to get accurate PPP in estuaries. Phytoplankton biodiversity analysis was also performed during this study, therefore the relationship between biodiversity, community structures and PPP will be explored in complement to this work. 


\section{References}

Alderkamp, A.-C., H. J. W. de Baar, R. J. W. Visser, and K. R. Arrigo. 2010. Can photoinhibition control phytoplankton abundance in deeply mixed water columns of the Southern Ocean? Limnology and Oceanography 55: 1248-1264.

Aminot, A., and M. Chaussepied. 1983. Manuel des analyses chimiques en milieu marin, CNEXO [ed.].

Aminot, A., and R. Kérouel. 2004. Hydrologie des écosystèmes marins: paramètres et analyses, Editions Quae.

Aminot, A., and R. Kérouel. 2007. Dosage automatique des nutriments dans les eaux marines. Méthodes d'analyse en milieu marin

Anning, T., H. L. Macintyre, S. M. Pratt, P. J. Sammes, S. Gibb, and R. J. Geider. 2000. Photoacclimation in the marine diatom Skeletonema costatum. Limnol. Oceanogr 45: 1807-1817.

Babin, M., A. Morel, H. Claustre, A. Bricaud, Z. Kolber, and P. G. Falkowski. 1996. Nitrogen- and irradiancedependent variations of the maximum quantum yield of carbon fixation in eutrophic, mesotrophic and oligotrophic marine systems. Deep Sea Research 43: 1241-1272.

Babin, M., A. Morel, and R. Gagnon. 1994. An incubator designed for extensive and sensitive measurements phytoplankton photosynthetic parameters. Limnology and Oceanography 39: 694-702.

Bailleul, B., N. Berne, O. Murik, D. Petroutsos, J. Prihoda, A. Tanaka, V. Villanova, R. Bligny, S. Flori, D. Falconet, A. Krieger-liszkay, S. Santabarbara, F. Rappaport, P. Joliot, L. Tirichine, P. G. Falkowski, P. Cardol, C. Bowler, and G. Finazzi. 2015. mitochondria drives CO 2 assimilation in diatoms. Nature 524: 366-369.

Barranguet, C., and J. Kromkamp. 2000. Estimating primary production rates from photosynthetic electron transport in estuarine microphytobenthos. Marine Ecology Progress Series 204: 39-52.

Boynton, W., W. Kemp, and C. Keefe. 1982. A comparative analysis of nutrients and other factors influencing estuarine phytoplankton production, p. 69-90/729. In V. Kennedy [ed.], Estuarine Comparisons: Proceedings of the Sixth Biennial International Estuarine Research Conference, Gleneden Beach, Oregon, November 1-6, 1981. Elsevier, 2013.

Brenon, I., and P. Le Hir. 1999. Modelling the Turbidity Maximum in the Seine Estuary ( France ): Identification of Formation. 525-544.

Campbell, D. A., V. Hurry, a K. Clarke, P. Gustafsson, and G. Oquist. 1998. Chlorophyll fluorescence analysis of cyanobacterial photosynthesis and acclimation. Microbiology and molecular biology reviews: MMBR 62: $667-683$.

Chen, C.-T. A., and A. V. Borges. 2009. Reconciling opposing views on carbon cycling in the coastal ocean: continental shelves as sinks and near-shore ecosystems as sources of atmospheric CO2. Deep-Sea Research Part II: Topical Studies in Oceanography 56: 578-590.

Chessel, D., A. B. Dufour, and J. Thioulouse. 2004. The ade4 package - I : One-table methods. R News 4: 5-10.

Claquin, P., S. NÍ Longphuirt, P. Fouillaron, P. Huonnic, O. Ragueneau, C. Klein, and A. Leynaert. 2010. Effects of simulated benthic fluxes on phytoplankton dynamic and photosynthetic parameters in a mesocosm experiment (Bay of Brest, France). Estuarine, Coastal and Shelf Science 86: 93-101.

Claquin, P., I. Probert, S. Lefebvre, and B. Veron. 2008. Effects of temperature on photosynthetic parameters and TEP production in eight species of marine microalgae. Aquatic Microbial Ecology 51: 1-11.

Cloern, J. E. 1996. Phytoplankton bloom dynamics in coastal ecosystems: A review with some general lessons from sustained investigation of San Francisco Bay, California. Reviews of Geophysics 34: 127-168.

Cloern, J. E., S. Q. Foster, and a. E. Kleckner. 2014. Phytoplankton primary production in the world's estuarinecoastal ecosystems. Biogeosciences 11: 2477-2501.

Davison, I. R. 1991. Environmental Effects on Algal Photosynthesis: Temperature. Journal of Phycology 27: 2-8.

Descy, J.-P., F. Darchambeau, T. Lambert, M. P. Stoyneva-Gaertner, S. Bouillon, and A. V. Borges. 2016. Phytoplankton dynamics in the Congo River. Freshwater Biology , doi:10.1111/fwb.12851

Dortch, Q., and T. E. Whitledge. 1992. Does nitrogen or silicon limit phytoplankton production in the Mississippi River plume and nearby regions? Continental Shelf Research 12: 1293-1309.

Dray, S., and A. B. Dufour. 2007. The ade4 Package: Implementing the Duality Diagram for Ecologists. Journal of Statistical Software 22: 1-20.

Dubinsky, Z., and N. Stambler. 2009. Photoacclimation processes in phytoplankton: Mechanisms, consequences, and applications. Aquatic Microbial Ecology 56: 163-176.

Eilers, P. H. C., and J. C. H. Peeters. 1988. A model for the relationship between light intensity and the rate of photosynthesis in phytoplankton. Ecological Modelling 42: 199-215.

Endo, T., and K. Asada. 2008. Photosystem I and Photoprotection: Cyclic Electron Flow andWater-Water Cycle, p. 
205-221. In Photoprotection, Photoinhibition, Gene Regulation, and Environment.

Etcheber, H., A. Taillez, G. Abril, J. Garnier, P. Servais, F. Moatar, and M. V. Commarieu. 2007. Particulate organic carbon in the estuarine turbidity maxima of the Gironde, Loire and Seine estuaries: Origin and lability. Hydrobiologia 588: 245-259.

Even, S., J. M. Mouchel, P. Servais, N. Flipo, M. Poulin, S. Blanc, M. Chabanel, and C. Paffoni. 2007. Modelling the impacts of Combined Sewer Overflows on the river Seine water quality. Science of the Total Environment 375: $140-151$.

Falkowski, P. G., and J. A. Raven. 1997. Carbon acquisition and assimilation. Aquatic photosynthesis $128-162$.

Garnier, J., G. Billen, J. Némery, and M. Sebilo. 2010. Transformations of nutrients (N, P, Si) in the turbidity maximum zone of the Seine estuary and export to the sea. Estuarine, Coastal and Shelf Science 90: $129-141$.

Genty, B., J. Harbinson, J. Briantais, N. R. Baker, and C. Lane. 1989. The relationship between non-photochemical quenching of chlorophyll fluorescence and the rate of photosystem 2 photochemistry in leaves. Photosynthesis research 25: 249-257.

Goosen, N. K., J. Kromkamp, J. Peene, P. Van Rijswijk, and P. Van Breugel. 1999. Bacterial and phytoplankton production in the maximum turbidity zone of three European estuaries: The Elbe, Westerschelde and Gironde. Journal of Marine Systems 22: 151-171.

Goss, R., and T. Jakob. 2010. Regulation and function of xanthophyll cycle-dependent photoprotection in algae. Photosynthesis research 106: 103-22.

Hama, T., T. Miyazaki, Y. Ogawa, T. Iwakuma, M. Takahashi, A. Otsuki, and S. Ichimura. 1983. Measurement of Photosynthetic Production of a Marine Phytoplankton Population Using a Stable 13C Isotope. Marine Biology 73: $31-36$.

Hancke, K., T. Dalsgaard, M. K. Sejr, S. Markager, and R. N. Glud. 2015. Phytoplankton Productivity in an arctic fjord (West Greenland): Estimating electron requirements for carbon fixation and oxygen production. PLoS ONE 10: 1-23.

Hartig, P., K. Wolfstein, S. Lippemeier, and F. Colijn. 1998. Photosynthetic activity of natural microphytobenthos populations measured by fluorescence (PAM) and 14C-tracer methods: A comparison. Marine Ecology Progress Series 166: 53-62.

Hernando, M., I. R. Schloss, G. Malanga, G. O. Almandoz, G. A. Ferreyra, M. B. Aguiar, and S. Puntarulo. 2015. Effects of salinity changes on coastal Antarctic phytoplankton physiology and assemblage composition. Journal of Experimental Marine Biology and Ecology 466: 110-119.

Holm-Hansen, O., A. F. Amos, and C. D. Hewes. 2000. Reliability of estimating chlorophyll a concentrations in Antarctic waters by measurement of in situ chlorophyll a fluorescence. Marine Ecology Progress Series 196: 103-110.

Hunter-Cevera, K. R., M. G. Neubert, R. J. Olson, A. R. Solow, A. Shalapyonok, and H. M. Sosik. 2016. Physiological and ecological drivers of early spring blooms of a coastal phytoplankter. Science 354: 326-329.

Hydes, D., M. Aoyama, A. Aminot, K. Bakker, S. Becker, S. Coverly, A. Daniel, A. G. Dickson, O. Grosso, R. Kerouel, J. van Ooijen, K. Sato, T. Tanhua, E. M. S. Woodward, and J. Z. Zhang. 2010. Determination of dissolved nutrients (N, P, Si) in seawater with high precision and inter-comparability using gas-segmented continuous flow analysers. The GO-SHIP Repeat Hydrography Manual IOCCP Report 134: 1-87.

Johnsen, G., and E. Sakshaug. 2007. Biooptical characteristics of PSII and PSI in 33 species (13 pigment groups) of marine phytoplankton, and the relevance for pulse-amplitude-modulated and fast-repetition-rate fluorometry 1. Journal of Phycology 43: 1236-1251.

Johnson, X., and J. Alric. 2013. Central carbon metabolism and electron transport in chlamydomonas reinhardtii: Metabolic constraints for carbon partitioning between oil and starch. Eukaryotic Cell 12: 776-793.

Jouenne, F., S. Lefebvre, B. Véron, and Y. Lagadeuc. 2007. Phytoplankton community structure and primary production in small intertidal estuarine-bay ecosystem (eastern English Channel, France). Marine Biology 151: 805-825.

Juneau, P., and P. J. Harrison. 2005. Comparison by PAM Fluorometry of Photosynthetic Activity of Nine Marine Phytoplankton Grown Under Identical Conditions. photochemistry and photobiology 649-653.

Kaiblinger, C., and M. T. Dokulil. 2006. Application of fast repetition rate fluorometry to phytoplankton photosynthetic parameters in freshwaters. Photosynthesis research 88: 19-30.

Kimmerer, W. J., A. E. Parker, U. E. Lidström, and E. J. Carpenter. 2012. Short-Term and Interannual Variability in Primary Production in the Low-Salinity Zone of the San Francisco Estuary. Estuaries and Coasts 35: 913-929.

Klughammer, C., and U. Schreiber. 2015. Apparent PS II absorption cross-section and estimation of mean PAR in optically thin and dense suspensions of Chlorella . Photosynthesis Research 123: 77-92.

Kolber, Z., and P. G. Falkowski. 1993. Use of active fluorescence to estimate phytoplankton photosynthesis in situ. 
Limnology and Oceanography 38: 1646-1665.

Kolber, Z. S., O. Prášil, and P. G. Falkowski. 1998. Measurements of variable chlorophyll fluorescence using fast repetition rate techniques: Defining methodology and experimental protocols. Biochimica et Biophysica Acta Bioenergetics 1367: 88-106.

Kromkamp, J. C., and R. M. Forster. 2003. The use of variable fluorescence measurements in aquatic ecosystems : differences between multiple and single turnover measuring protocols and suggested terminology. European Journal of Phycology 38: 103-112.

Kromkamp, J. C., and J. Peene. 2005. Changes in phytoplankton biomass and primary production between 1991 and 2001 in the Westerschelde estuary (Belgium/The Netherlands). Hydrobiologia 540: 117-126.

Lawrenz, E., G. Silsbe, E. Capuzzo, P. Ylöstalo, R. M. Forster, S. G. H. Simis, O. Prášil, J. C. Kromkamp, A. E. Hickman, C. M. Moore, M.-H. Forget, R. J. Geider, and D. J. Suggett. 2013. Predicting the electron requirement for carbon fixation in seas and oceans. PloS one 8: e58137.

Lionard, M., K. Muylaert, D. Van Gansbeke, and W. Vyverman. 2005. Influence of changes in salinity and light intensity on growth of phytoplankton communities from the Schelde river and estuary (Belgium/The Netherlands). Hydrobiologia 540: 105-115.

Lohrenz, S. E., G. L. Fahnenstiel, D. G. Redalje, G. A. Lang, M. J. Dagg, T. E. Whitledge, and Q. Dortch. 1999. Nutrients, irradiance, and mixing as factors regulating primary production in coastal waters impacted by the Mississippi River plume. Continental Shelf Research 19: 1113-1141.

Lorenzen, C. J. 1966. A method for the continuous measurement of in vivo chlorophyll concentration. Deep Sea Research and Oceanographic Abstracts 13: 223-227.

Macintyre, H. L., T. M. Kana, T. Anning, and R. J. Geider. 2002. Review Photoacclimatation of photosynthesis Irradiance response curves and photosynthetic pigments in microalgae and cyanobacteria. Journal of Phycology 38: 17-38.

Magnien, R. E., R. M. Summers, and K. G. Sellner. 1992. External Nutrient Sources, Internal Nutrient Pools, and Phytoplankton Production in Chesapeake Bay. Estuaries 15: 497.

Mallin, M. A., H. W. Paerl, J. Rudek, and P. W. Bates. 1993. Regulation of estuarine primary production by watershed rainfall and river flow. Marine Ecology Progress Series 93: 199-203.

Masojidek, J., J. Grobbelaar, L. Pechar, and M. Koblizek. 2001. Photosystem II electron transport rates and oxygen production in natural waterblooms of freshwater cyanobacteria during a diel cycle. Journal of Plankton Research 23: 57-66.

Milligan, A. J., K. H. Halsey, and M. J. Behrenfeld. 2014. HORIZONS: Advancing interpretations of 14C-uptake measurements in the context of phytoplankton physiology and ecology. Journal of Plankton Research 37: 692698.

Morris, A. W., A. J. Bale, and R. J. M. Howland. 1981. Nutrient distributions in an estuary: Evidence of chemical precipitation of dissolved silicate and phosphate. Estuarine, Coastal and Shelf Science 12: 205-216.

Morris, E. P., and J. C. Kromkamp. 2003. Influence of temperature on the relationship between oxygen- and fluorescence-based estimates of photosynthetic parameters in a marine benthic diatom (Cylindrotheca closterium). European Journal of Phycology 38: 133-142.

Napoléon, C., and P. Claquin. 2012. Multi-Parametric Relationships between PAM Measurements and Carbon Incorporation, an In Situ Approach. PloS one 7: 1-12.

Napoléon, C., L. Fiant, V. Raimbault, and P. Claquin. 2013a. Study of dynamics of phytoplankton and photosynthetic parameters using opportunity ships in the western English Channel. Journal of Marine Systems 128: $146-158$.

Napoléon, C., L. Fiant, V. Raimbault, P. Riou, and P. Claquin. 2014. Dynamics of phytoplankton diversity structure and primary productivity in the english channel. Marine Ecology Progress Series 505: 49-64.

Napoléon, C., V. Raimbault, and P. Claquin. 2013b. Influence of Nutrient Stress on the Relationships between PAM Measurements and Carbon Incorporation in Four Phytoplankton Species. PLoS ONE 8, doi:10.1371/journal.pone.0066423

Napoléon, C., V. Raimbault, L. Fiant, P. Riou, S. Lefebvre, L. Lampert, and P. Claquin. 2012. Spatiotemporal dynamics of physicochemical and photosynthetic parameters in the central English Channel. Journal of Sea Research 69: 43-52.

Némery, J., and J. Garnier. 2007. Origin and fate of phosphorus in the Seine watershed (France): Agricultural and hydrographic P budgets. Journal of Geophysical Research: Biogeosciences 112: 1-14.

Ning, X., D. Vaulot, Z. Liu, and Z. Liu. 1988. Standing stock and production of phytoplankton in the estuary of the Chang-jiang (Yangste River) and the adjacent East China Sea . Marine Ecology Progress Series 49: 141-150.

Nixon, S. W. 1995. Coastal marine eutrophication: a definition, social causes, and future concerns. Ophelia 41: 199- 
219.

Nogales, J., S. Gudmundsson, E. M. Knight, B. O. Palsson, and I. Thiele. 2011. Detailing the optimality of photosynthesis in cyanobacteria through systems biology analysis. PNAS 109: 2678_2683.

Pannard, A., P. Claquin, C. Klein, B. Le Roy, and B. Véron. 2008. Short-term variability of the phytoplankton community in coastal ecosystem in response to physical and chemical conditions' changes. Estuarine, Coastal and Shelf Science 80: 212-224.

Parizzi, R. A., E. Da, C. Machado, C. Prestes, D. Santos, L. F. Fernandes, M. G. De Camargo, L. Laureno, and M. Jr. 2016. Primary productivity and phytoplankton dynamics in a subtropical estuary: a multiple timescale approach. Scientia Marina 80: 1-13.

Parkhill, J. P., G. Maillet, and J. J. Cullen. 2001. Fluorescence-based maximal quantum yield for PSII as a diagnostic of nutrient stress. Journal of Phycology 37: 517-529.

Passy, P., R. Le Gendre, J. Garnier, P. Cugier, J. Callens, F. Paris, G. Billen, P. Riou, and E. Romero. 2016. Eutrophication modelling chain for improved management strategies to prevent algal blooms in the Bay of Seine. Marine Ecology Progress Series 543: 107-125.

Pauly, D., and V. Christensen. 1995. Primary production required to sustain global fisheries. 374: $255-257$.

Pennock, J., and J. Sharp. 1986. Phytoplankton production in the Delaware Estuary: temporal and spatial variability . Marine Ecology Progress Series 34: 143-155.

Sanford, L. P., S. E. Suttles, and J. P. Halka. 2001. Reconsidering the Physics of the Chesapeake Bay Estuarine Turbidity Maximum. Estuaries 24: 655.

Schreiber, U., C. Klughammer, and J. Kolbowski. 2012. Assessment of wavelength-dependent parameters of photosynthetic electron transport with a new type of multi-color PAM chlorophyll fluorometer. Photosynthesis research 113: 127-44.

Schreiber, U., U. Schliwa, and W. Bilger. 1986. Continuous recording of photochemical and non-photochemical chlorophyll fluorescence quenching with a new type of modulation fluorometer. Photosynthesis research 10: 51-62.

Schuback, N., C. Schallenberg, C. Duckham, M. T. Maldonado, and P. D. Tortell. 2015. Interacting Effects of Light and Iron Availability on the Coupling of Photosynthetic Electron Transport and CO2-Assimilation in Marine Phytoplankton. Plos One 10: e0133235.

Servais, P., and J. Garnier. 2006. Organic carbon and bacterial heterotrophic activity in the maximum turbidity zone of the Seine estuary (France). Aquatic Sciences 68: 78-85.

Sferratore, A., J. Garnier, G. Billen, D. J. Conley, and S. Pinault. 2006. Diffuse and point sources of silica in the Seine River Watershed. Environmental Science and Technology 40: 6630-6635.

Sharp, J. H., C. H. Culberson, and T. M. Church. 1982. The chemistry of the Delaware estuary. General considerations. Limnology and Oceanography 27: 1015-1028.

Shaw, P. J., and D. A. Purdie. 2001. Phytoplankton photosynthesis-irradiance parameters in the near-shore UK coastal waters of the North Sea: Temporal variation and environmental control. Marine Ecology Progress Series 216: 83-94.

Shelly, K., P. Heraud, J. Beardall, and E. T. Al. 2003. note interactive effects of PAR and uv-b radiation on PSII electron transport in the marine alga dunaliella tertiolecta ( chlorophyceae ) To better understand the interactions between PAR and UV-B radiation in microalgae. Journal of Phycology 512: 509-512.

Smith, E. M., and W. M. Kemp. 1995. Seasonal and regional variations in plankton community production and respiration for Chesapeake Bay. Marine Ecology Progress Series 116: 217-232.

Sorokin, Y. I., and P. Y. Sorokin. 1996. Plankton and primary production in the Lena River estuary and in the southeastern Laptev Sea. Estuarine, Coastal and Shelf Science 43: 399-418.

van Spaendonk, J. C. M., J. C. Kromkamp, and P. R. M. de Visscher. 1993. Primary production of phytoplankton in a turbid coastal plain estuary, the Westerschelde (The Netherlands). Netherlands Journal of Sea Research 31: 267-279.

Suggett, D. J., H. L. MacIntyre, and R. J. Geider. 2004. Evaluation of biophysical and optical determinations of light absorption by photosystem II in phytoplankton. Limnology and Oceanography: Methods 2: 316-332.

Tillmann, U., K.-J. Hesse, and F. Colijn. 2000. Planktonic primary production in the German Wadden Sea. Journal of Plankton Research 22: 1253-1276.

Underwood, G. J. C., and J. Kromkamp. 1999. Primary Production by Phytoplankton and Microphytobenthos in Estuaries. Advances in Ecological Research 29: 93-153.

Vegter, F. 1977. The closure of the grenvelingen estuary: its influence on phytoplankton primary production and nutrient content. Hydro 52: 67-71.

Verney, R., R. Lafite, and J. C. Brun-Cottan. 2009. Flocculation potential of estuarine particles: The importance of 
environmental factors and of the spatial and seasonal variability of suspended particulate matter. Estuaries and Coasts 32: 678-693.

Wang, Z. B., M. C. J. L. Jeuken, H. Gerritsen, H. J. De Vriend, and B. A. Kornman. 2002. Morphology and asymmetry of the vertical tide in the Westerschelde estuary. Continental Shelf Research 22: 2599-2609.

Zhu, Y., J. Ishizaka, S. C. Tripathy, S. Wang, Y. Mino, T. Matsuno, and D. J. Suggett. 2016. Variation of the photosynthetic electron transfer rate and electron requirement for daily net carbon fixation in Ariake Bay, Japan. Journal of Oceanography 72: 761-776.

Fig. 1 Map of the Seine estuary (Longitude: 0.2327, latitude: 49.4326 (WGS84) - Normandy, France) showing the study area. Poses is the upper limit of tidal propagation. The lowest map is a close-up of the square site in the right upper map corresponding to the sampling area. The sampling transect from site 1 to site 8 followed the salinity gradient from the euhaline zone (Site 1) to the oligohaline zone (site 8). The sites were sampled monthly throughout 2015

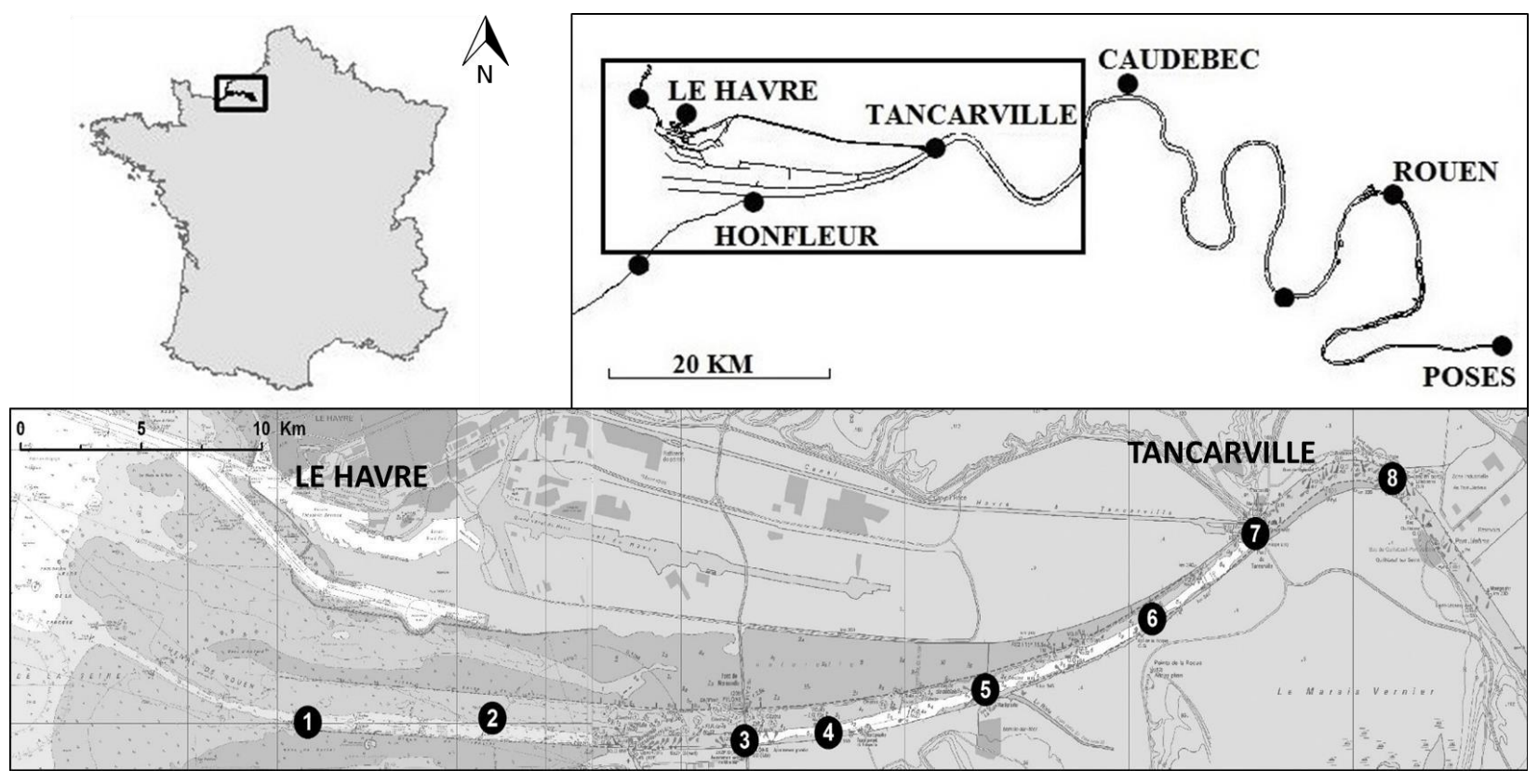


Fig. 2. Schematic diagram of the sampling strategy for high frequency measurement of photosynthetic parameters. A pump-connected pipe was immersed to subsurface $(1 \mathrm{~m})$ from the ship deck, and water was introduced periodically ( $5 \mathrm{~min}$ interval) to the insulated dark tank for dark-adaptation of photosystem, and then automatically flowed into the PAM flow-through chamber for measurement of photosynthetic parameters. The water flow was controlled by solenoid valve automatically activated using a homemade software. The device was controlled semi-automatically as it was necessary to adjust the gains and performed blank between some samples according to chl a concentration variability. Therefore, an operator was necessary to control the device.

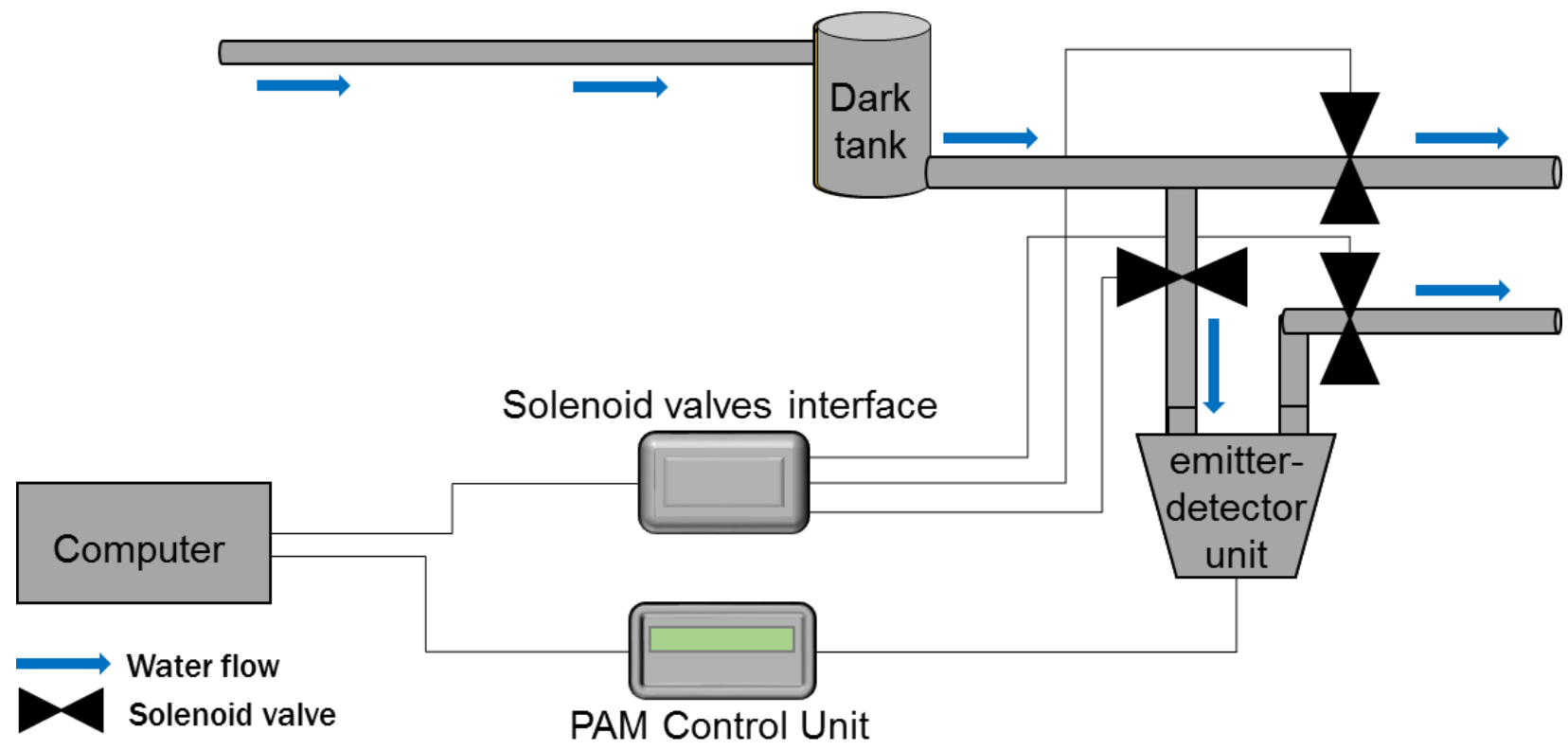


Fig. 3. Interstructure analysis of the partial triadic analysis (PTA) performed on physical-chemical parameters in the sub-surface layer: (A) Histogram of eigenvalues based on the diagonalization of the RV matrix, (B) ordination of the sites given by the two first eigenvectors of the vector correlation matrix and (C) tree topology obtained by Ward's clustering method and for the bottom layer: (D) Histogram of eigenvalues based on the diagonalization of the RV matrix and (E) ordination of the sites given by the two first eigenvectors of the vector correlation matrix

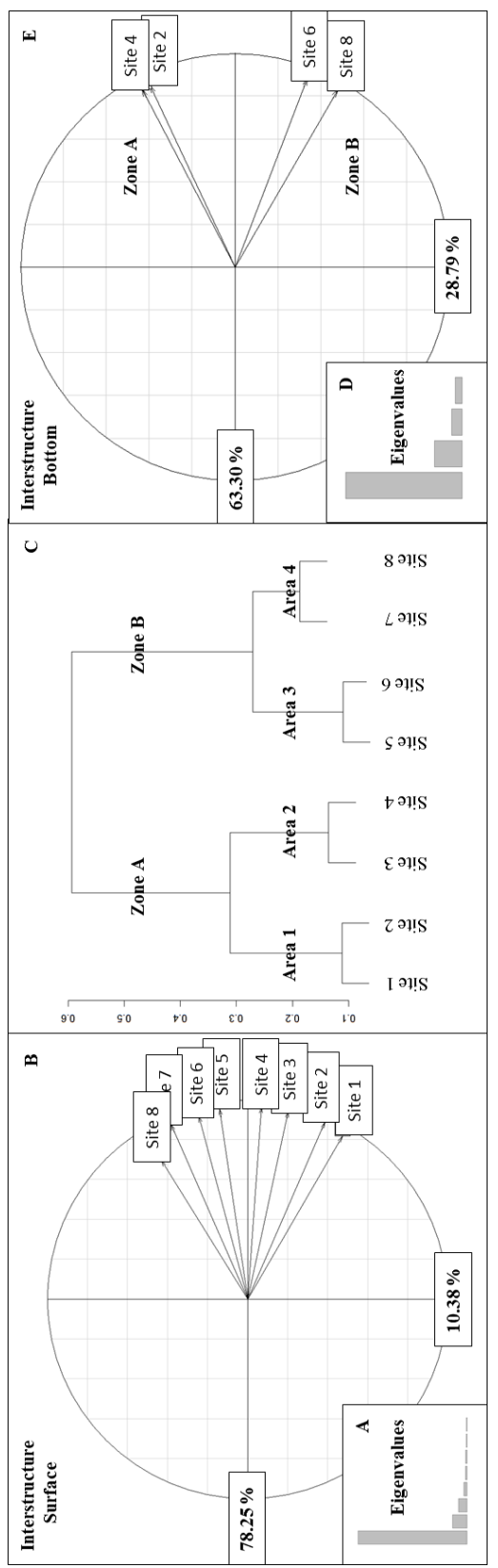


Fig. 4 Compromise analysis of the partial triadic analysis (PTA) performed on physical-chemical parameters in the sub-surface waters: Histogram of eigenvalues (A), projection of the variables (B) and the sampling dates (C) in the plane defined by the two first axes and for bottom waters: Histogram of eigenvalues (D), projection of the variables $(\mathrm{E})$ and the sampling dates $(\mathrm{F})$ in the plane defined by the two first axes

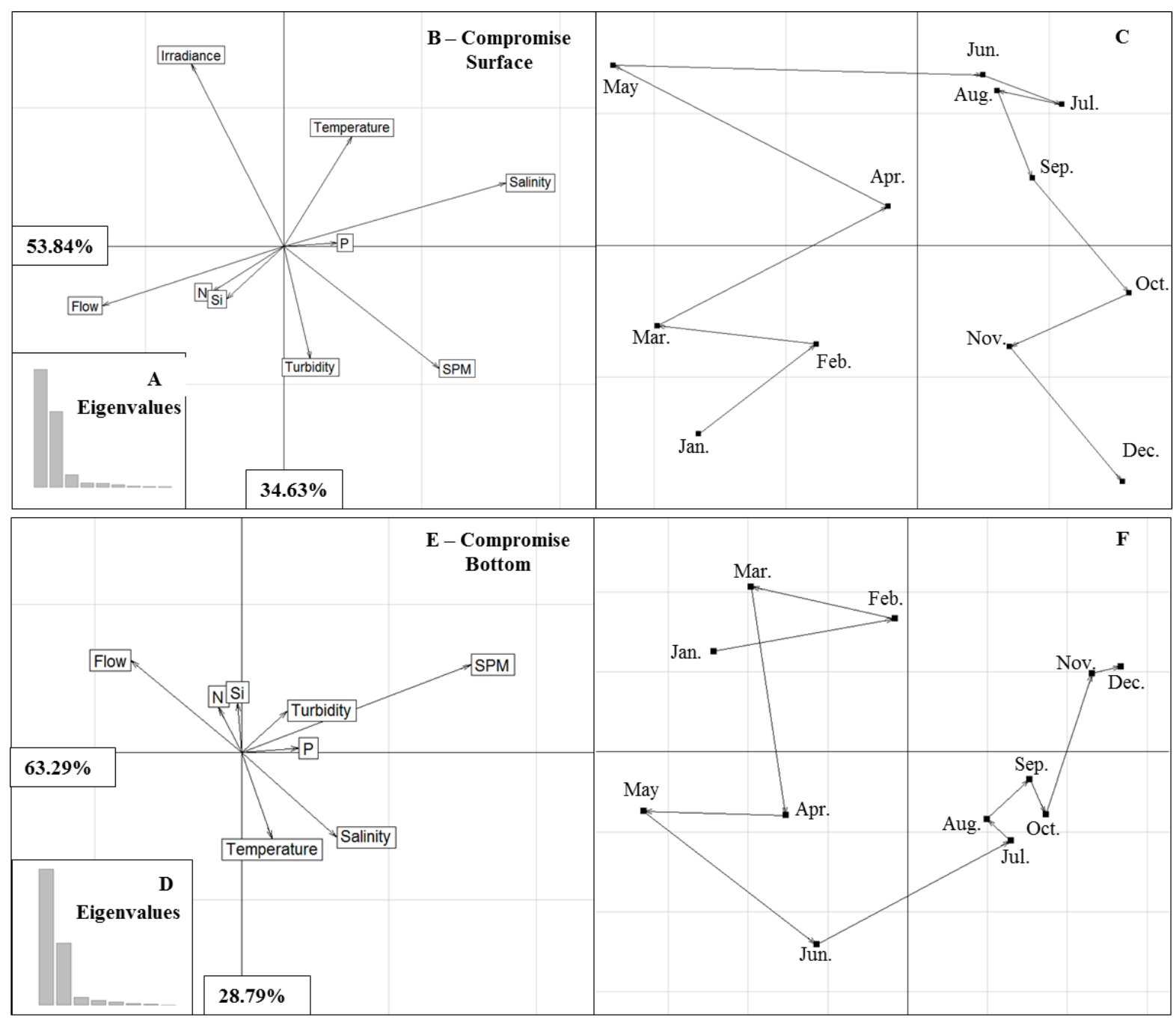


Fig. 5 Variations in biomass (chla concentration; $\mu \mathrm{g} . \mathrm{L}^{-1}$ ) and the maximum quantum efficiency of PSII $\left(\mathrm{F}_{\mathrm{V}}: \mathrm{F}_{\mathrm{M}}\right.$; rel.unit) representing the physiological state of the cells in the Seine estuary from January to December, 2015. The sub-surface layer $(1 \mathrm{~m})$ is shown in the left panel and the bottom layer (1 $\mathrm{m}$ above the WSI) in the right panel

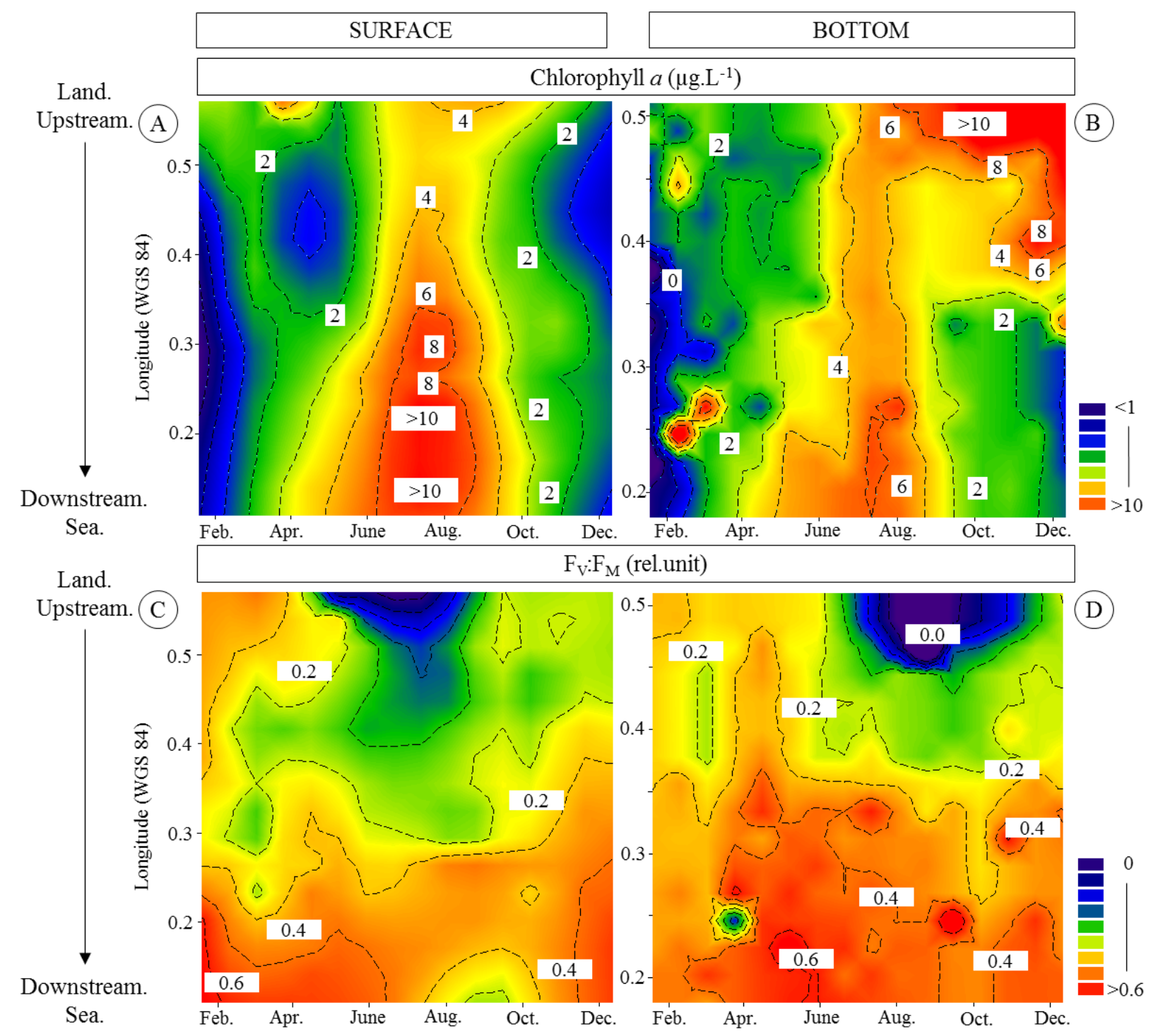


Fig. 6 Variations in the low maximum light utilization efficiency $\left(\alpha(\mathrm{II})\right.$; mmol electron.mgchla.h ${ }^{-1} \cdot(\mu \mathrm{mol}$ photon $\left.\mathrm{m}^{-2} \mathrm{~s}^{-1}\right)^{-1}$ ) in the Seine estuary from January to December, 2015. This parameter was measured at high frequency in the sub-surface layer of water all along the sampling transect at monthly intervals

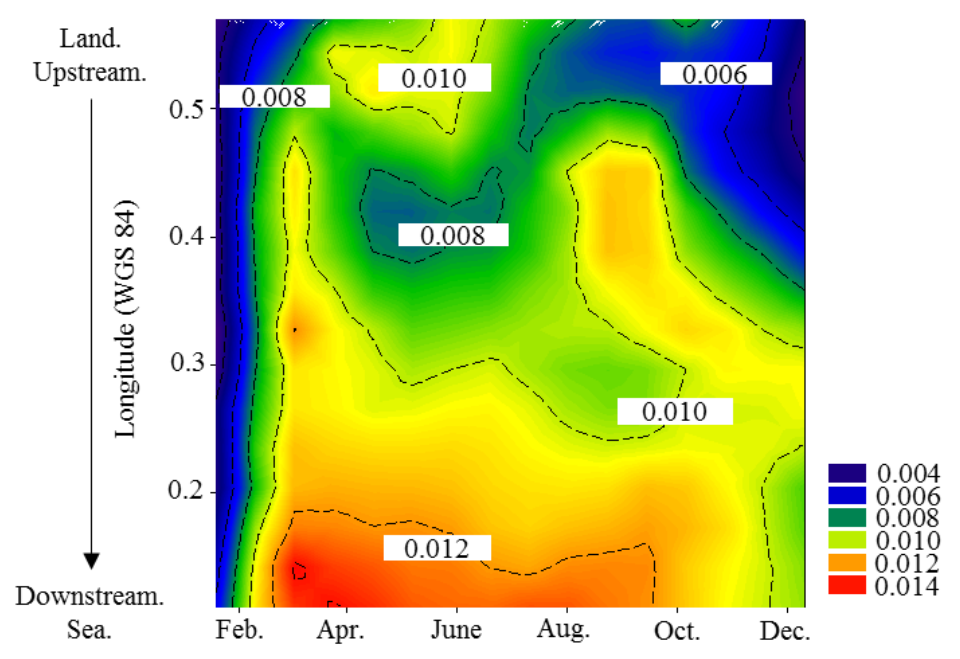

Fig. 7 Variations in the maximum electron transport rate (ETR(II) $)_{\max } ;$ mmol electron.mgchl $\left.{ }^{-1} \cdot \mathrm{h}^{-1}\right)$ in the Seine estuary from January to December, 2015. The ETR(II) max $_{\text {ax }}$ was measured at five minute intervals in the sub-surface layer of water all along the sampling transect at monthly intervals

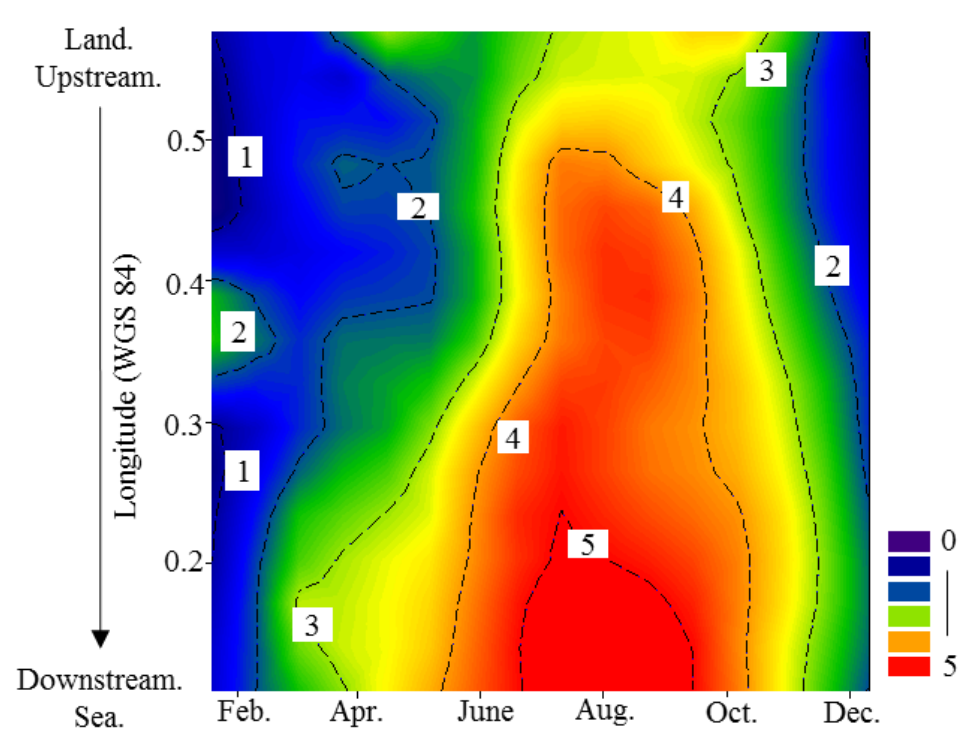




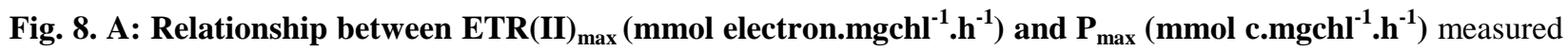
in the Seine estuary from January to December, 2015. B: Relationship between ETR(II) max $_{\text {(mmol electron.mgchl }}$ $\left.{ }^{1} \cdot \mathbf{h}^{-1}\right)$ and $\mathbf{P}_{\text {max }}^{\text {sim }}\left(\mathbf{m m o l} \mathbf{c} . \mathrm{mgchl}^{-1} \cdot \mathbf{h}^{-\mathbf{1}}\right)$ calculated using the following equation : $\mathrm{P}_{\max }^{\operatorname{sim}}=0.43-1.19 \cdot 10^{-2} \times$ $\operatorname{ETR}(\mathrm{II})_{\max }-9.75 \cdot 10^{-4} \times[\mathrm{DIN}]+1.29 \cdot 10^{-2} \times$ Temperature (eq. 15 in the text).

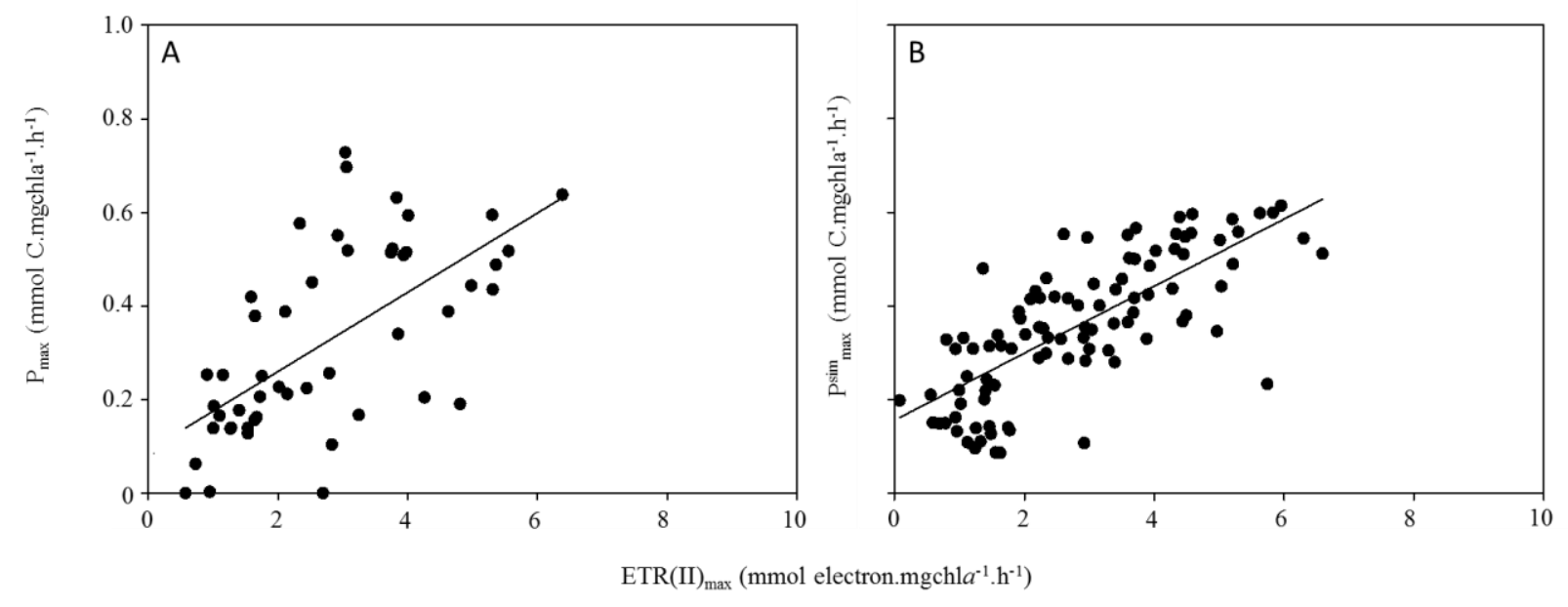

Fig. 9 Dynamics of electron requirements for $C$ fixation $\left(\varphi_{e, C}\right)$ in the Seine estuary from January to December, 2015

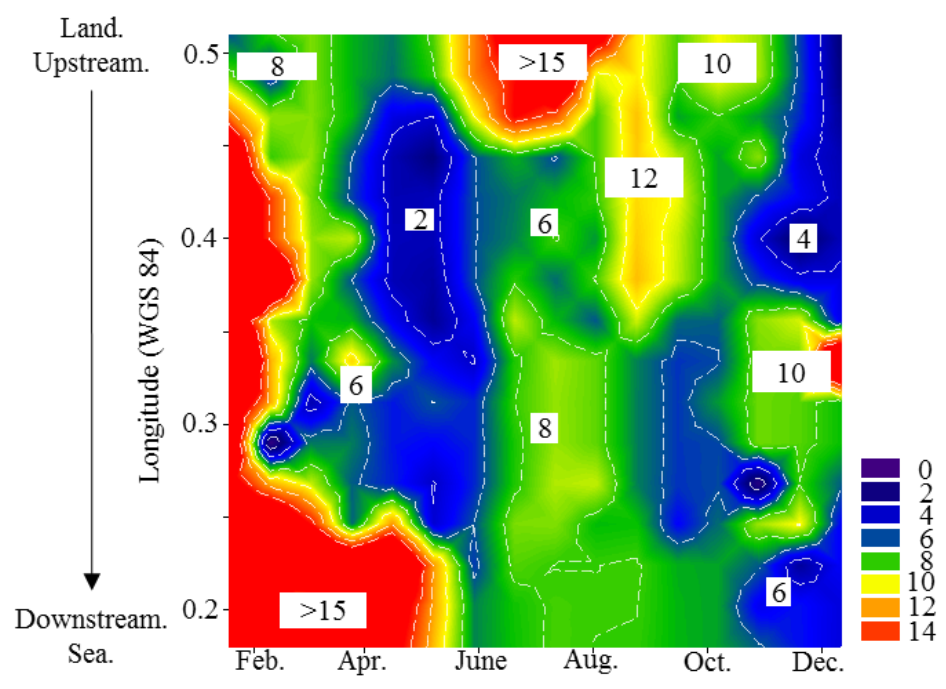


Fig. 10 Dynamics of daily phytoplankton primary production (left; $\mathrm{mgC} \cdot \mathrm{m}^{-2} \cdot \mathrm{d}^{-1}$ ) and P:B ratio (right; $\mathrm{mgC} . \mathrm{mgchl} a^{-1} \cdot \mathrm{d}^{-1}$ ) along the Seine estuary from "Le Havre" (longitude 0.09) to "Tancarville" (Longitude 0.51) in 2015. PP was estimated as a function of hourly irradiance and integrated over depth
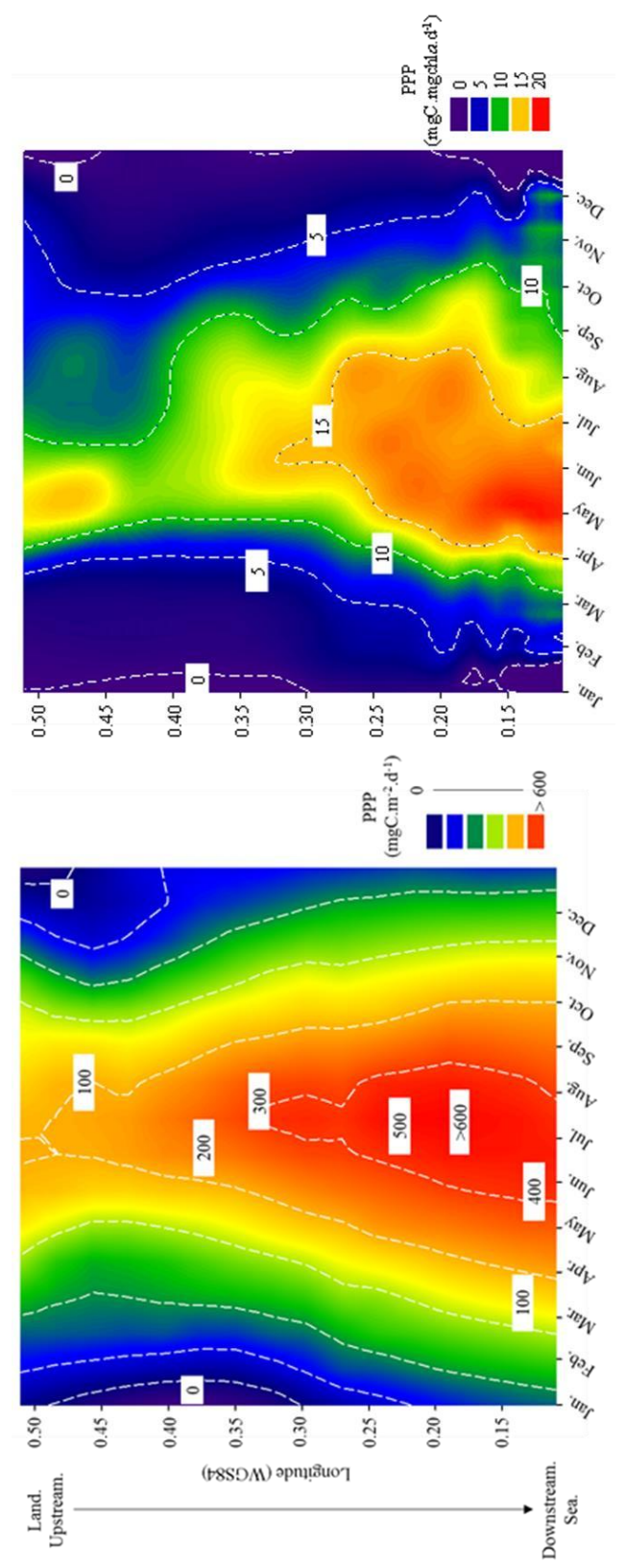
Fig. 11 Principal component analysis factor loading plot in the plane defined by the two axes for sub-surface waters. (A) zone A (sites 1 to 4 ) and (B) zone B (sites 5 to 8) and for bottom waters with (D) zone A and (E) zone B. White labels show active variables and grey labels illustrative variables

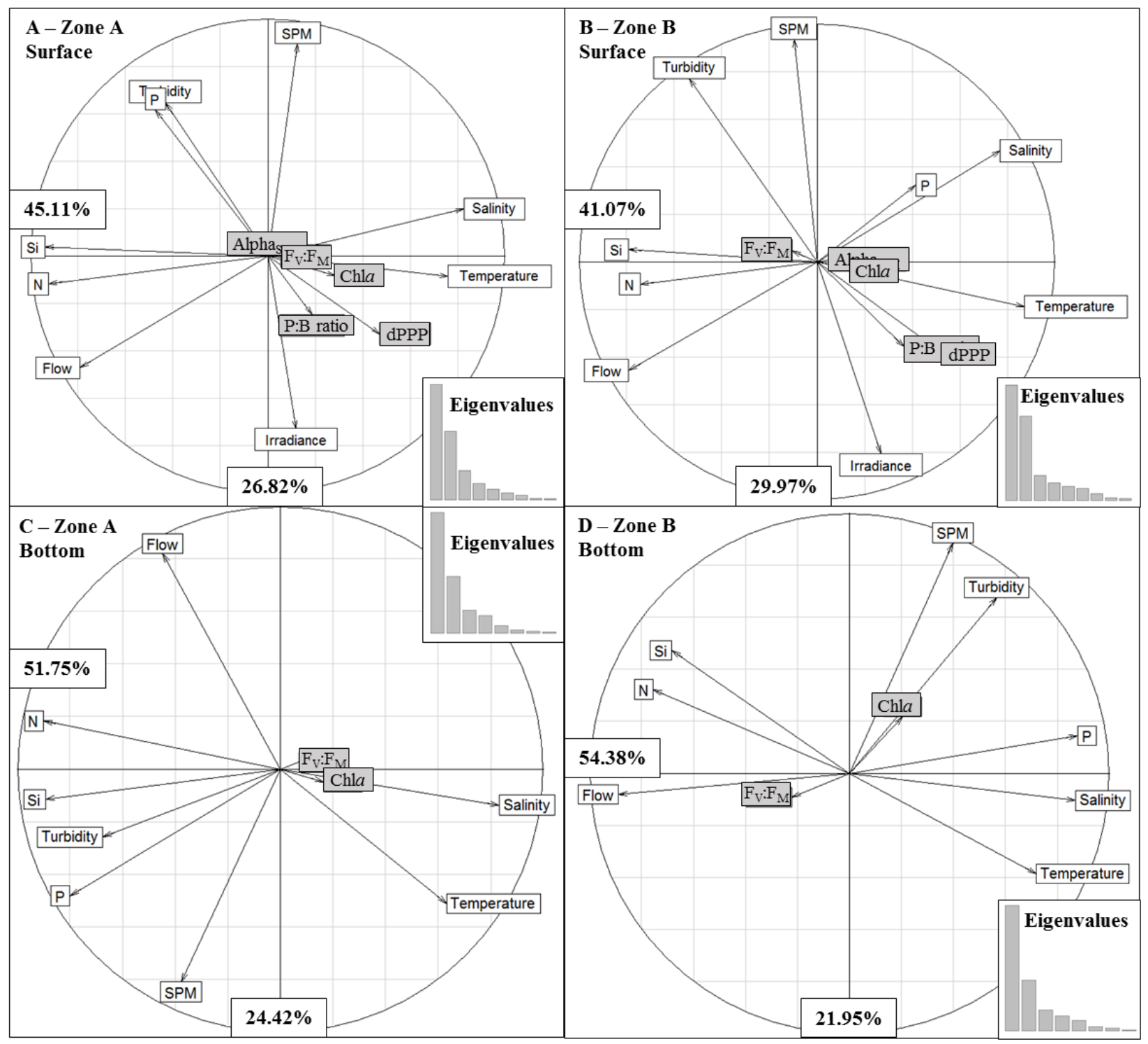


Table 1. Matrix of the RV-coefficients between the sub-matrix and the weight of each sub-matrix in the construction of the compromise

\begin{tabular}{|c|c|c|c|c|c|c|c|c|c|}
\hline Sites & 1 & 2 & 3 & 4 & 5 & 6 & 7 & 8 & Weight \\
\hline \multicolumn{10}{|c|}{ Surface } \\
\hline 1 & 1.00 & & & & & & & & 0.33 \\
\hline 2 & 0.89 & 1.00 & & & & & & & 0.35 \\
\hline 3 & 0.82 & 0.90 & 1.00 & & & & & & 0.38 \\
\hline 4 & 0.76 & 0.86 & 0.95 & 1.00 & & & & & 0.38 \\
\hline 5 & 0.69 & 0.78 & 0.86 & 0.90 & 1.00 & & & & 0.38 \\
\hline 6 & 0.62 & 0.69 & 0.80 & 0.86 & 0.94 & 1.00 & & & 0.37 \\
\hline 7 & 0.55 & 0.61 & 0.72 & 0.81 & 0.89 & 0.92 & 1.00 & & 0.35 \\
\hline 8 & 0.44 & 0.51 & 0.57 & 0.60 & 0.63 & 0.60 & 0.67 & 1.00 & 0.28 \\
\hline \multicolumn{10}{|c|}{ Bottom } \\
\hline 2 & & 1.00 & & & & & & & 0.50 \\
\hline 4 & & 0.76 & & 1.00 & & & & & 0.49 \\
\hline 6 & & 0.62 & & 0.56 & & 1.00 & & & 0.52 \\
\hline 8 & & 0.50 & & 0.51 & & 0.80 & & 1.00 & 0.49 \\
\hline
\end{tabular}

Table 2. Estimation of phytoplankton primary production $\left(\mathrm{gC} \cdot \mathrm{m}^{-2} \cdot \mathrm{m}^{-1}\right)$ for each month (from January to December) and at each site (from 1 to 8). The minimum and maximum daily PPP $\left(\mathrm{gC}^{-\mathrm{m}^{-2}} \cdot \mathrm{d}^{-1}\right)$ are given and an annual PPP (in $\mathrm{gC} \cdot \mathrm{m}^{-2} \cdot \mathrm{y}^{-1}$ and in tC. $\left.\mathrm{y}^{-1}\right)$ was calculated for each site (bottom row). A mean PPP $\left(\mathrm{gC} \cdot \mathrm{m}^{-2} \cdot \mathrm{m}^{-1}\right)$ was calculated for each month (last column on the right) and on average for the estuary (last cell on the bottom right)

\begin{tabular}{|c|c|c|c|c|c|c|c|c|c|}
\hline Site & 1 & 2 & 3 & 4 & 5 & 6 & 7 & 8 & Mean $\left(\mathrm{gC} \cdot \mathrm{m}^{-2}\right)$ \\
\hline January & 0.27 & 0.22 & 0.11 & 0.05 & 0.01 & 0.03 & 0.02 & 0.09 & 0.10 \\
\hline February & 1.53 & 1.06 & 0.72 & 0.38 & 0.37 & 0.37 & 0.44 & 0.27 & 0.64 \\
\hline April & 7.47 & 5.61 & 2.35 & 2.09 & 0.87 & 0.33 & 0.15 & 0.88 & 2.47 \\
\hline May & 15.14 & 9.78 & 4.65 & 2.79 & 1.87 & 1.89 & 3.24 & 4.43 & 5.47 \\
\hline August & 8.58 & 19.87 & 7.56 & 8.34 & 8.76 & 2.05 & 6.66 & 3.06 & 8.11 \\
\hline September & 3.33 & 3.46 & 3.01 & 2.66 & 1.12 & 1.12 & 0.93 & 1.14 & 2.10 \\
\hline October & 2.57 & 2.60 & 1.01 & 1.49 & 1.60 & 0.70 & 0.36 & 1.32 & 1.45 \\
\hline November & 1.99 & 0.87 & 0.82 & 0.84 & 0.21 & 0.05 & 0.01 & 0.89 & 0.71 \\
\hline Annual PPP $\left(\mathrm{gC} \cdot \mathrm{m}^{-2} \cdot \mathrm{y}^{-1}\right)$ & 72.13 & 81.53 & 50.68 & 45.68 & 31.16 & 17.26 & 17.62 & 18.54 & - \\
\hline Surface $\left(\mathrm{km}^{-2}\right)$ & 44.38 & 23.07 & 9.81 & 4.27 & 3.79 & 2.61 & 2.26 & 2.96 & - \\
\hline Annual PPP (tC. $\left.y^{-1}\right)$ & 3200 & 1881.3 & 497.15 & 195.26 & 118.15 & 45.09 & 39.84 & 54.92 & $64.75 \mathrm{gC} \cdot \mathrm{m}^{-2} \cdot \mathrm{y}^{-1}$ \\
\hline
\end{tabular}




\section{Supplementary material}

\section{Title}

Annual phytoplankton primary production estimation in a temperate estuary by coupling PAM and carbon incorporation methods

\section{Journal name}

Estuaries and coasts

\section{Authors}

Jérôme Morelle ${ }^{1,2}$; Mathilde Schapira ${ }^{3,4}$; Francis Orvain ${ }^{1,2}$; Philippe Riou ${ }^{3}$; Pascal Jean Lopez ${ }^{2}$; Olivier Pierre-Duplessix ${ }^{3,4}$; Emilie Rabiller ${ }^{3}$; Frank Maheux ${ }^{3}$; Benjamin Simon $^{3}$; \& Pascal Claquin ${ }^{1,2^{*}}$

\section{Institutional affiliation}

${ }^{1}$ Normandie Université, Université de Caen Normandie, F-14032 Caen, France

${ }^{2}$ Unité Biologie des ORganismes et Ecosystèmes Aquatiques (BOREA, UMR 7208), Sorbonne Universités, Muséum National d'Histoire Naturelle, CNRS, Université Pierre et Marie Curie, Université de Caen Normandie, IRD 207, Université des Antilles, CP 26, 43 rue Cuvier, 75005 Paris, France ${ }^{3}$ Ifremer, LER/N, Avenue du Général de Gaulle, 14520 Port-en-Bessin, France

${ }^{4}$ Present address : Ifremer, LER/MPL/NT, Rue de L'Ile d'Yeu BP 21105, 44301 Nantes CEDEX 03, France.

*corresponding author: pascal.claquin@unicaen.fr ; +332315651 12 or +33_2_31_36_22_33 


\section{Hydrological parameters}

The Seine River flow decreased progressively from January to July 2015 with the maximum values reaching $1240 \mathrm{~m}^{3} \cdot \mathrm{s}^{-1}$ in February and May (Fig. 12). Between July and November, the flow was around $500 \mathrm{~m}^{3} \cdot \mathrm{s}^{-}$ 1 , and the minimum value $\left(155 \mathrm{~m}^{3} \cdot \mathrm{s}^{-1}\right)$ was observed at the beginning of August. An increase in flow was recorded at the end of November.

The irradiance level was affected by a typical seasonal trend, with the highest value $\left(1.13 \times 10^{8} \mu \mathrm{mol}\right.$ photons. $\mathrm{m}^{-2} \cdot \mathrm{d}^{-1}$ ) observed in June (Fig. 12).

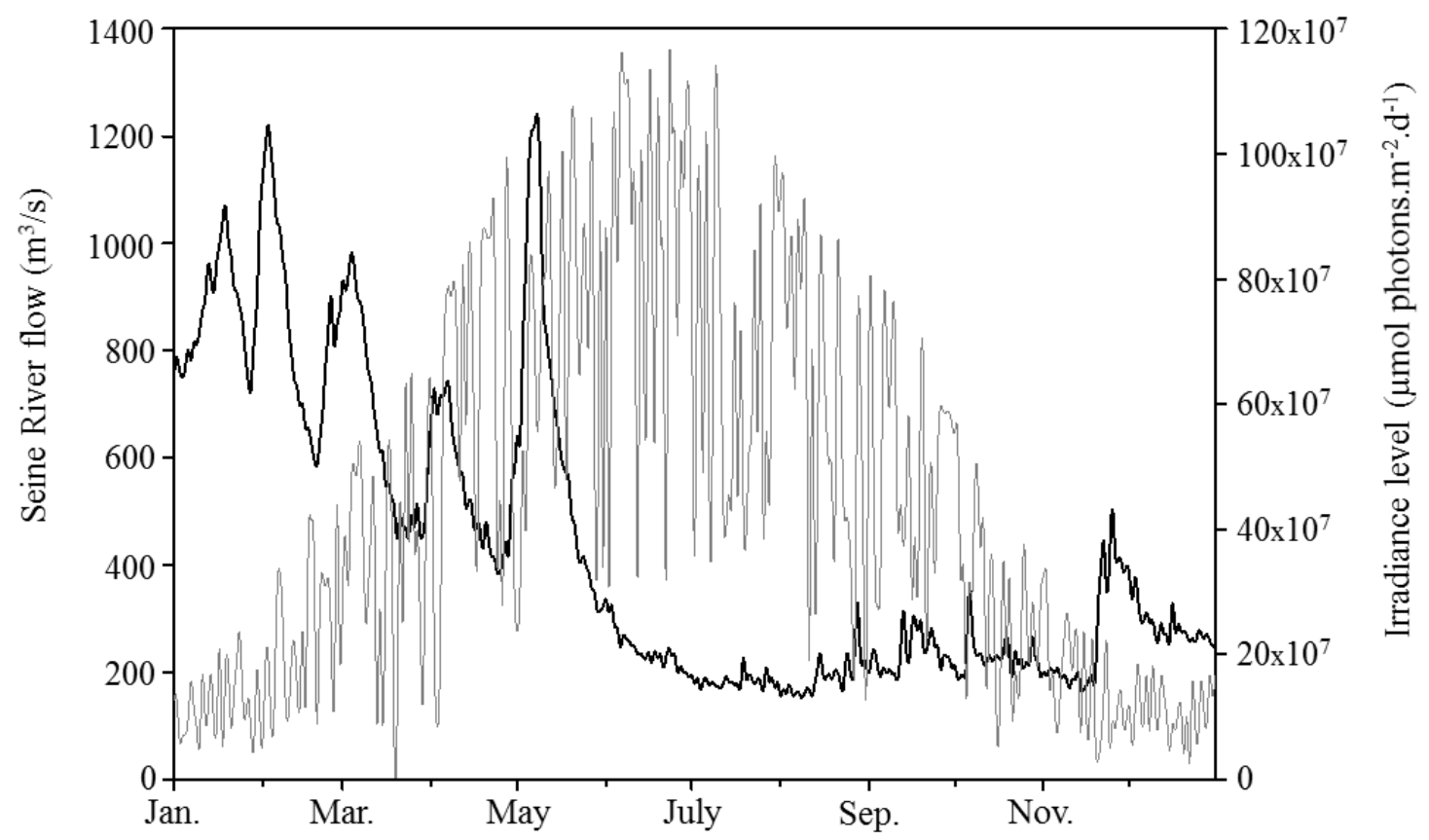

Figure 12. Daily irradiance level (grey $-\mu$ mol photons. $\mathrm{m}^{-2} \cdot \mathrm{d}^{-1}$ ) and river flow (black $-\mathrm{m}^{3} \cdot \mathrm{s}^{-1}$ ) in the Seine estuary during the sampling year (2015).

Water temperature followed a typical seasonal pattern over the course of the year (Fig. 13). The highest temperature $\left(21.89{ }^{\circ} \mathrm{C}\right)$ was measured in sub-surface water in July and the lowest $\left(5.12{ }^{\circ} \mathrm{C}\right)$ was measured close to the WSI in February in the oligohaline zone. Close to the WSI, the temperature was more heterogeneous with patches of cold or warm water. An inversion of the temperature gradient was observed over the course of the year in sub-surface, with temperature increasing from downstream to upstream in winter, and inversely in summer.

Salinity showed a dilution gradient in sub-surface from downstream to upstream (Fig. 13). While a similar gradient was observed close to the WSI, it was more disparate and patches of fresh or salty water were observed. The highest salinity value (29.9) was measured close to the WSI at site 2 in November. 


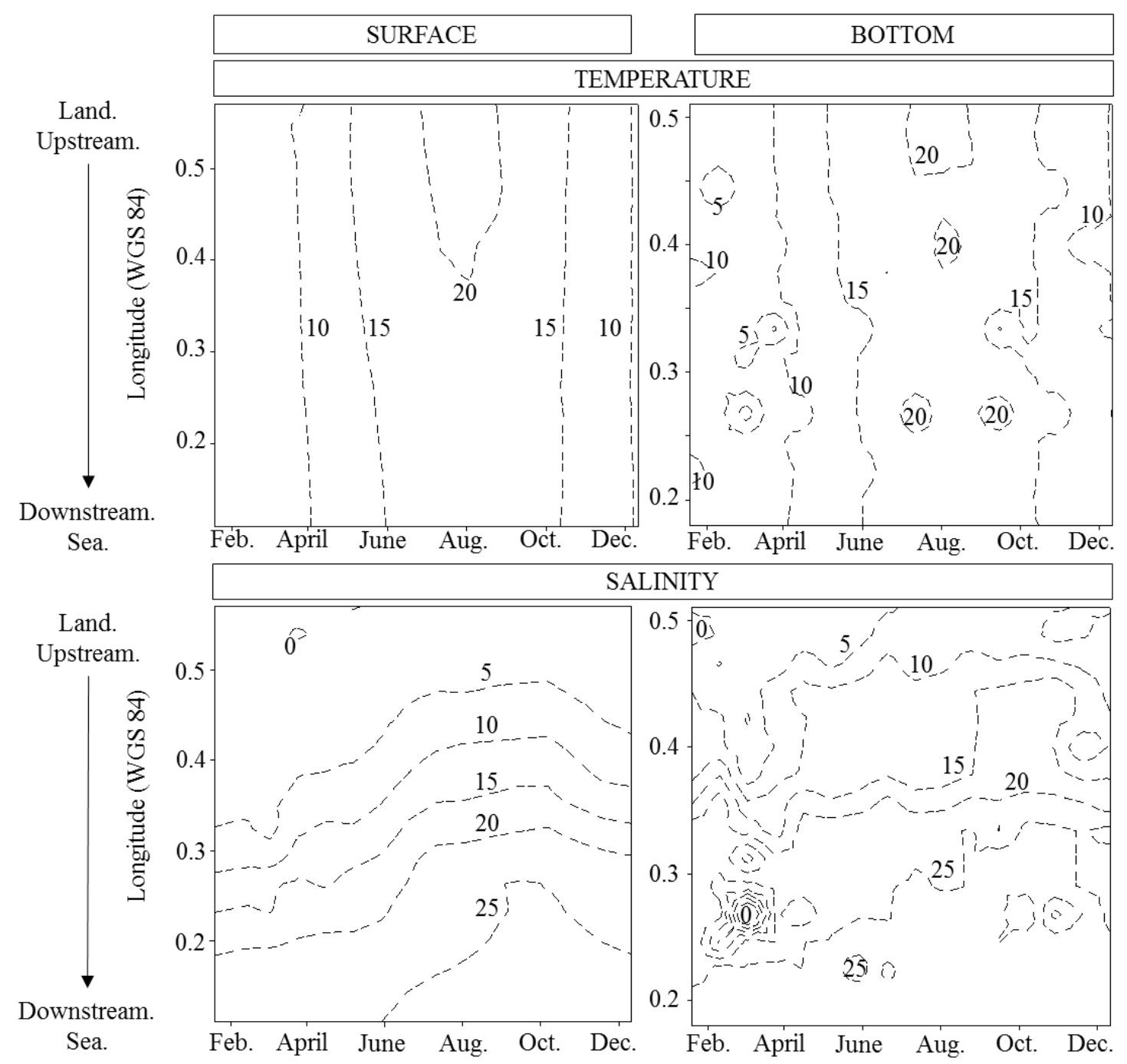

Figure 13 Salinity (PSU) and temperature $\left({ }^{\circ} \mathrm{C}\right)$ of the Seine estuary from January to December, 2015. The sub-surface layer $(1 \mathrm{~m})$ is shown in the left panel and the bottom layer $(1 \mathrm{~m}$ above the WSI) in the right panel.

The highest concentrations of SPM were measured in winter in both sub-surface and bottom waters (Fig. 14). In sub-surface waters, the concentrations were often homogeneous along the salinity gradient. Some patches of higher concentration were observed close to the WSI out of the MTZ. The MTZ was located at site 8 from January to February, and at site 5 from November to December, with values with values higher than 0.1 g.L $\mathrm{L}^{-1}$ in sub-surface. Close to the WSI, SPM concentrations were higher (>0.2 g.L $\left.\mathrm{L}^{-1}\right)$ especially in the MTZ, with a maxima of 2.7 g.L. $\mathrm{L}^{-1}$ observed in December at site 8. A correlation was found between SPM concentrations and turbidity (Person correlation coefficient: $0.58, \mathrm{p}<0.001, \mathrm{n}=148$ ) throughout the salinity gradient and over the entire studied period. Turbidity (Fig. 14) presented a clear gradient in the sub-surface water with an increase in turbidity values from downstream to upstream and confirmed the position of the MTZ previously defined with SPM concentrations. 

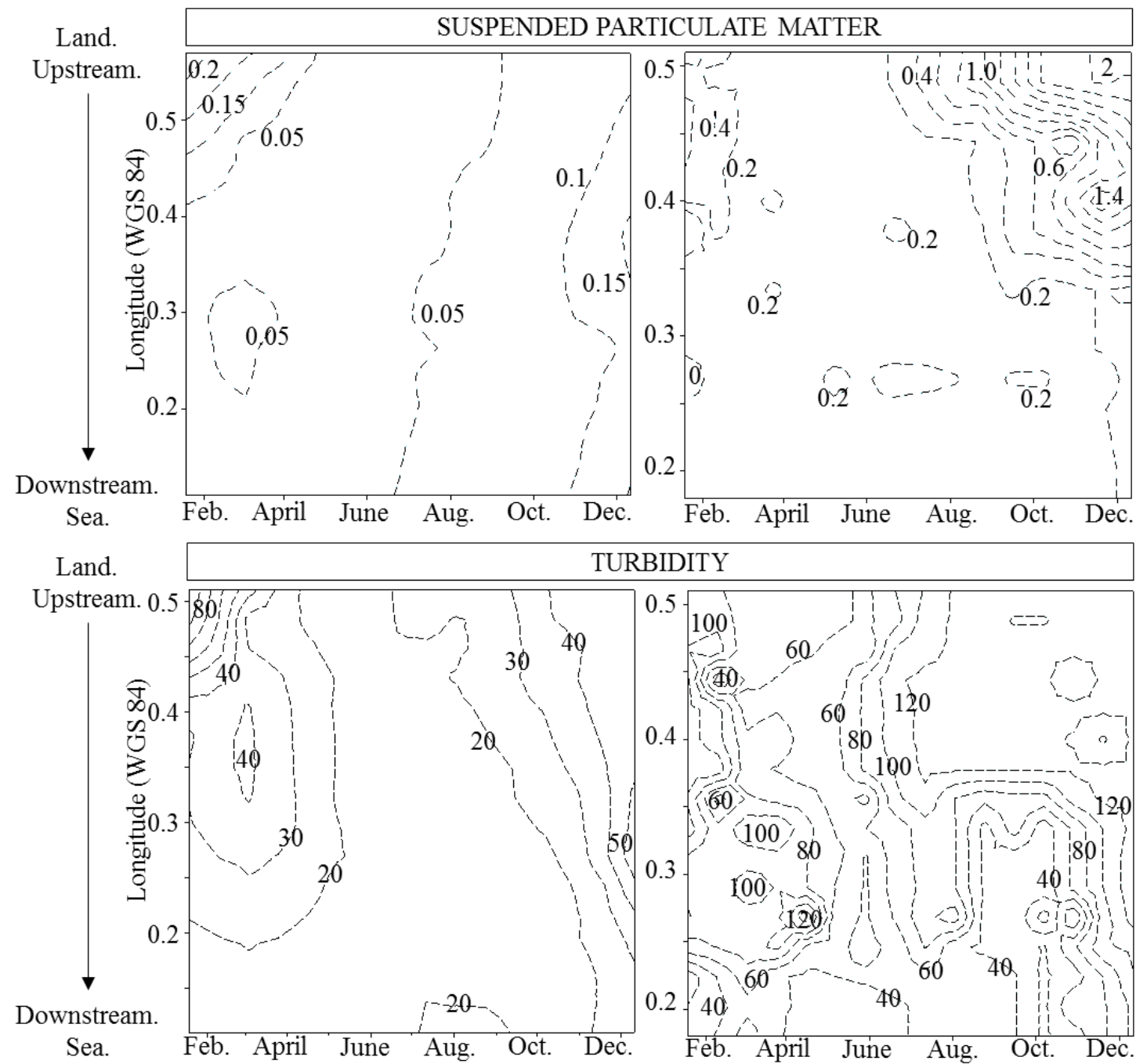

Figure 14 Suspended particulate matter (g.. $\left.{ }^{-1}\right)$ and turbidity (NTU) in the Seine estuary from January to December, 2015. The sub-surface layer $(1 \mathrm{~m})$ is shown in the left panel and the bottom layer $(1 \mathrm{~m}$ above the WSI) in the right panel.

The concentrations of DIN and silicates were higher in sub-surface waters than in close to the WSI throughout the salinity gradient and over the entire studied period (Fig. 15). The highest values were always observed in the MTZ especially during the flood period (up to $482 \mu$ mol. $\mathrm{L}^{-1}$ for nitrates and $165.5 \mu \mathrm{mol} . \mathrm{L}^{-1}$ for silicates). The lowest concentration of DIN $\left(40.9 \mu \mathrm{mol} . \mathrm{L}^{-1}\right)$ was measured close to the WSI in August and the lowest concentrations of silicates $\left(17 \mu \mathrm{mol} \cdot \mathrm{L}^{-1}\right)$ in May, both at site 2 . In sub-surface waters, a clear pattern of dilution was observed for DIN concentrations with a decrease in [DIN] values from upstream to downstream. Close to the WSI, the concentrations of DIN were more disparate along the salinity gradient, despite a dilution being observed from upstream to downstream. The dilution pattern of the silicates was similar to the DIN pattern at both depth (Person correlation coefficient: 0.88, $\mathrm{p}<0.001, \mathrm{n}=148$ ). Phosphate concentrations followed a different pattern characterized by weak differences between sub-surface and bottom waters throughout the salinity gradient (Fig. 15). The highest values $\left(>4 \mu \mathrm{mol} . \mathrm{L}^{-1}\right.$ ) were observed upstream close to the WSI at sites 7 , $8 \& 9$ in August, and the lowest value $\left(0.6 \mu\right.$ mol. $\left.\mathrm{L}^{-1}\right)$ was measured close to the WSI at site 2 in May. In March, a patch of freshwater was observed close to the WSI at site 3 (longitude 0.27 ), characterized by low salinity, high turbidity and high concentrations of nutrients. 

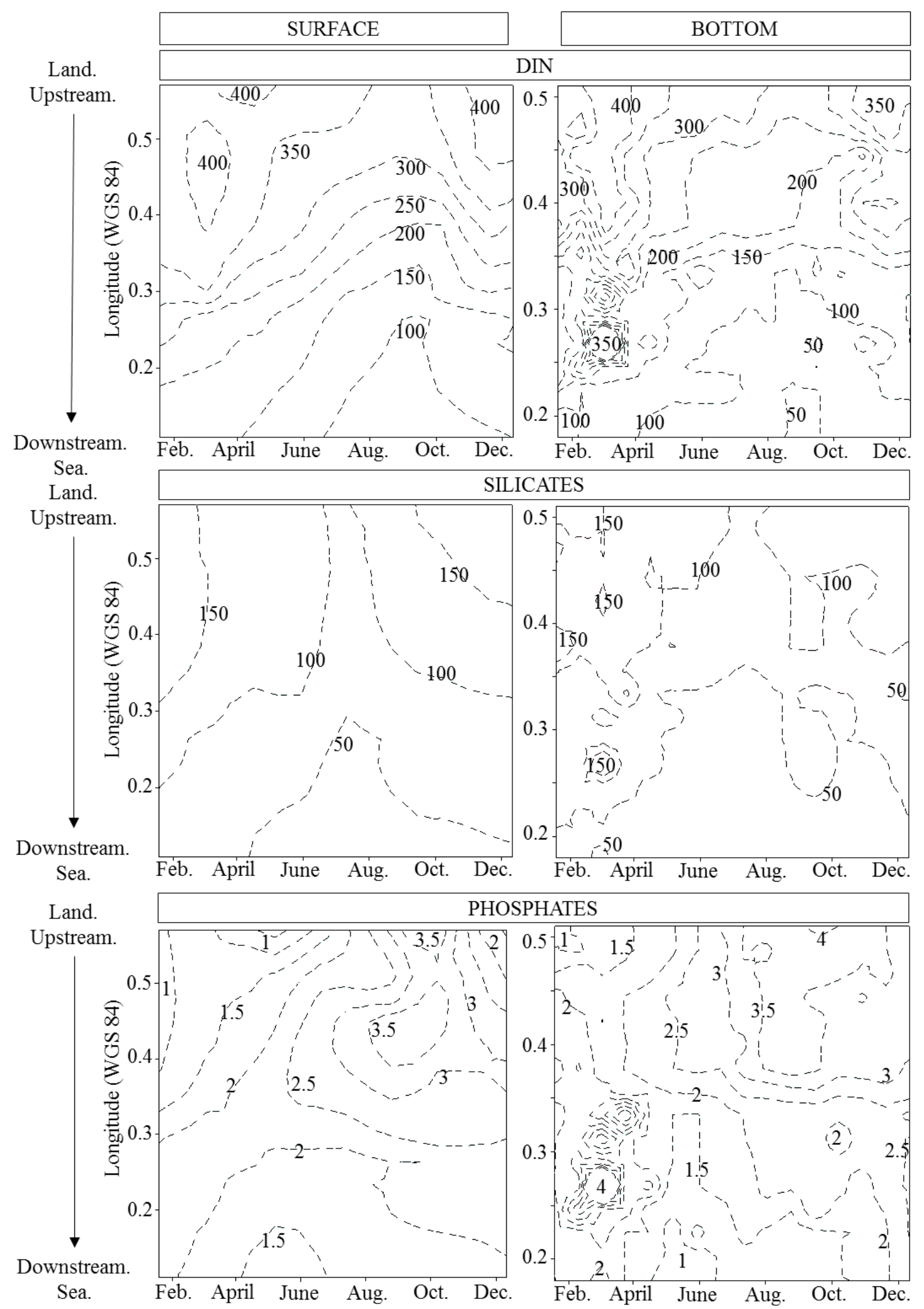

Figure 15. Variations in nutrient concentrations (DIN $\left(\mathrm{NO}_{3}^{-}+\mathrm{NO}_{2}^{-}+\mathrm{NH}_{4}{ }^{+}\right)$, silicates $\left(\mathrm{Si}(\mathrm{OH})_{4}\right)$ and phosphates $\left(\mathrm{PO}_{4}^{3-}\right)$ in $\mu$ mol. $\left.\mathrm{L}^{-1}\right)$ in the Seine estuary from January to December, 2015. The sub-surface layer $(1 \mathrm{~m})$ is shown in the left panel and the bottom layer (1 $\mathrm{m}$ above the WSI) in the right panel. 